\title{
Lawrence Kohlberg's Cognitive Moral Development Theory and the Ideal Human Developed By Religion
}

\author{
Hulya Cetin \\ Canakkale Onsekiz Mart University, Faculty of Theology, Canakkale, Turkey \\ E-mail: hulyacetin@comu.edu.tr
}

\begin{abstract}
Morality has also existed among those who have no faith, as well as those who have a religious and moral belief throughout history. Morality can be defined as a set of attitudes, behaviors, and rules that a particular community has to adhere to the values, norms, principles, or people living in the community. Kohlberg's moral development theory, a theory that is recognized at international level and the basis for many studies. Kohlberg stated that people had six moral judicial phases. The six jurisdictions were also discussed in three levels. According to Kohlberg, people in all cultures use the same basic moral concepts as justice, equality, love, respect, authority. In addition, all individuals, regardless of cultural differences, depending on these concepts and in the same order, they go through the stages of reasoning. The difference between individuals arises only in terms of how far they move and how far they progress.

On the other hand, an ideal human being is tried to be found in the religions by accepting a strong motivation source in terms of both presenting the moral principles that are appropriate to their own creation, and encouraging people to act according to these principles.
\end{abstract}

Keywords: Kohlberg, Religion, Education, morality, human

DOI: $10.7176 / \mathrm{JSTR} / 5-12-04$

\section{Lawrence Kohlberg'in Bilişssel Ahlak Gelişim Kuramı ve Dinlerin Hedeflediği İdeal İnsan ${ }^{1}$}

\begin{abstract}
Özet
Ahlak, tarih boyunca her hangi bir dini ve ahlaki inancı olanlar kadar, bir inancı olmayanlar arasında da var olagelmiştir. Ahlak belirli bir topluluğun değer yargıları, normları, ilkeleri ya da topluluk içinde yaşayan kişilerin uymak zorunda olduğu tutum, davranış ve kurallar bütünü olarak tanımlanabilir.

Kohlberg'in ahlak gelişim teorisi, uluslararası düzeyde kabul gören ve pek çok çalışmaya temel teşkil eden bir teoridir. Kohlberg kuramını evrelere ayırarak anlatmaya çalışmıştır. Kohlberg, insanların altı ahlaki yargı evresi geçirdiklerini belirtmiştir. Altı yargı evresini de, üç düzey içinde ele almıştır. Kohlberg'e göre, bütün kültürdeki insanlar adalet, eşitlik, sevgi, saygı, otorite gibi aynı temel ahlaki kavramları kullanmaktadırlar. Ayrıca bütün bireyler, kültür farklılığına bakılmaksızın, bu kavramlara bağlı olarak ve aynı düzen içinde akıl yürütme evrelerinden geçerler. Bireyler arasındaki farklılık, yalnızca evreleri ne hızda geçtikleri ve nereye kadar ilerledikleri açısından ortaya çıkmaktadır.

Öte yandan dinlerde, gerek kişilere kendi yaratılışlarına uygun olan ahlaki prensipleri sunması, gerekse kişileri bu prensiplere uygun davranmaya sevk etmesi bakımından güçlü bir motivasyon kaynağı kabul edilerek hedeflenen bir ideal insan ortaya çıkarılmaya çalışılmaktadır.
\end{abstract}

Anahtar Kelimeler: Kohlberg, Din, Eğitim, Ahlak, İnsan.

\footnotetext{
${ }^{I}$ Bu çalışma 28-30 NiSAN 2018 tarihlerinde Antalya'da düzenlenen I. Uluslararası Sosyal Araştırmalar ve Davranış Bilimleri (SADAB) Sempozyumu'nda sunulan bildirinin geliștirilmiş halidir.
} 


\section{Giriş}

İnsanlık tarihi boyunca; peygamberler, filozoflar ve eğitimciler gibi pek çok kanaat lideri tarafindan ideal insan modeli ve ideal toplum biçimleri oluşturulmaya çalışılmıştır. Bu amaçla, yüzyıllar boyunca pek çok ahlak sistemi kurulmuştur. Bu sistemlerin birçoğu geçmişte dini karakterli iken; küreselleşme ve modern bir yaşamla birlikte, özellikle psikolog ve eğitimciler tarafından geliştirilen ahlak gelişim teorileri ise, seküler bir özellik taşımaktadır. Bu teorilerin en önemlilerinden biri de, Kohlberg'in bilişsel ahlak gelişim teorisidir. Kohlberg'in ahlak gelişim teorisi, gerek yurtdışında gerekse yurtiçinde uzun yıllardır ahlakla ilgili pek çok çalışmaya temel teşkil etmiştir.

Ahlak, "moral" kelimesiyle ifade edilmekte olup yüzyıllar boyu filozof ve din adamlarının spekülasyonlarına ve araştırmalarına konu olmuştur. (Çileli, 1986:30-32) Ahlak, belirli bir topluluğun değer yargıları, normları, ilkeleri ya da topluluk içinde yaşayan kişilerin uymak zorunda olduğu tutum, davranış ve kurallar bütünü olarak tanımlanabilir. (Atayman, 2005:20-22) Bazı bilim insanları çalışmalarında Kohlberg'in ahlak tanımına yer vermişlerdir. Bu çalışmaya göre ahlak, "hak-haksızlık, doğru-yanlış, iyi-kötü konularında bilinçli yargılama ve karar vermeyi ve bu karar doğrultusunda davranışta bulunmayı kapsayan türe özgü bilişsel bir yapıdır. Bir başka deyişle, bilişsel bir yetenek olan ahlak, bireyin kendisinin belirlediği ve aynı zamanda evrensel ilkeler ile örtüşebilecek düzeydeki ilkelere göre yargıda bulunma, kararlar alma ve bu doğrultuda davranabilmedir. (Kerbs vd.,1997:131-145) Güngör'e göre ahlak; doğruyu yanlıştan ayırt etmek, bu ayrıma göre davranmak, erdemli davranışlarla onur duygusunu yaşamak ve insanın, eylemleri için suçluluk veya utanç duyma yeteneği anlamlarına gelmektedir. Ahlaki davranışın en ayırt edici özelliği, insanların ve düşüncelerin iyi ve kötü hükümler çerçevesinde ele alınmasıdır. (Güngör, 2010:24-28)

İslâm ahlâkçılarının ortak tanımıyla da ahlak; "nefiste yerleşmiş olan öyle bir meleke der ki, bu meleke sayesinde davranışlarımız kolaylıkla ve uzun uzun düşünmeden ortaya çıkar.”(Katip Çelebi, 1947:35) Yani ahlak sürekli yapılan bir eylem olduğu için alışkanlık haline gelmesinden dolayı kişinin zorlanmadan davranışa dönüştürebileceği bir huy haline gelir.

Eğer bireyin aldığı huylar iyi ise iyi huyu, kötü ise kötü huylu olarak ifade ediyoruz. Kişinin iyi ya da kötü huylu olmasında aldığı eğitimin, sosyal çevrenin ve din algısının yeri çok önemlidir.

Bir toplumda ahlak ilkelerinin uygulanabilir olması için ihtiyaç duyduğu temel yaptırımları dört kategoride ele alabiliriz: Sosyal bask1, vicdan, doğal yaptırım ve dinsel yaptırım. (Erdem, 2003:95-96) Bu yaptırımların ilki olan sosyal baskı ve sosyal ödüllenmedir ki bu yaptırım toplumun bireyi kontrolüdür diyebiliriz. Belli bir kuralın yapılmaması kişinin toplumda ayıplanmasına ve kınanmasına sebep olacağından bu yaptırım oldukça güçlü bir etkiye sahiptir. Bergson, sosyal baskıyı hissederek ahlak kurallarını yerine getirmeye 'aşağı ahlak' demekte ve erdemle ilişkilendirmemektedir. (Topçu, 1998:121)

İkinci yaptırım ise; Vicdandır. Vicdan; bireyin, ya toplumla uzlaşarak 'kötü' kabul ettiği veya kendince, kendi kriterlerine göre kötü saydığı bir eylemi yapması durumunda hissettiği iç rahatsızlık, huzursuzluk veya aksine, ya yine toplumla birlikte kendisinin ya da yalnızca kendisinin 'iyi’ olarak kabul ettiği bir eylemi yapması sonucunda duyduğu iç huzur ve rahatlık olarak tanımlanabilir. Birey bazen çok uzun zaman sonra bile, yaptığı 'kötü' bir eylemi itiraf ederek, cezasını çekip vicdanını rahatlatmak isteyebilir. Kur'ân-1 Kerîm'de vicdan kelimesi geçmemekle birlikte birçok âyette insanda bulunan ve onun iradî fiillerini ahlâk ölçülerine göre denetleyen, iyilik yapmaktan sevinç, kötülük yapmaktan ıstırap duyan bir ahlâkî melekeden söz edildiği, tövbenin de böyle bir vicdanî hesaplaşmanın ürünü sayıldığı görülür.(enNisâ ,4:17-18; el-Mâide 5:38-39; en-Nahl 16:119) Kur'an'da insanın psikolojik yapısıyla ilgili olarak en çok geçen kelimelerden nefis, vicdanın tesirini de içine alan geniş bir anlama sahiptir. İnsanın kişiliğini ve benliğini meydana getiren, bütün yeteneklerinin merkezi olan ve çeşitli mertebelerden teşekkül eden nefsin benmerkezci ve hazcı durumuna "nefs-i emmâre" (Yûsuf 12:53) kendini sorgulama ve değerlendirme boyutuna "nefs-i levvâme",(el-Kıyâme 75:2) dinî ve ahlâkî değerlerle tam uyumlu en üst basamağına da "nefs-i mutmainne" (el-Fecr 89/27-28) denmiştir. Kur'an’a göre nefis, vicdanî boyutu sayesinde kendini denetleme ve buna göre ödül veya ceza verme yetkisine sahiptir.(el-Enbiyâ 21:64; enNeml 27:14) Nefsin iyilik ve kötülükleri ayırt edebilecek şekilde yaratıldığını, nefsini arındıranın ebedî kurtuluşa ereceğini, onu kirletenin ise ziyana uğrayacağını ifade eden ayetlerdeki (eş-Şems 91:7-10) nefis kelimesi de vicdanı hatırlatmaktadır.

Üçüncü yaptırım ise doğal yaptırımdır. Bu anlayışa göre doğa, insanların yaptığı kötü ve iyi eylemlere kendi diliyle cevap vermekte, onları ya cezalandırmakta veya ödüllendirmektedir. Doğanın insandan beklediği orta yolu izlemesidir: orta yolu aşan veya orta yola ulaşamayanı doğa her zaman cezalandırır. (Erdem, 2003:95) Örneğin, aşırı hedonist bir anlayışla haz için her türlü eylemi yapabilen bir insanı doğa, hastalık vb. bir sonuçla cezalandırabilir; fazla içki içmek eylemini gerçekleştiren bir birey bunun cezasını fizyolojik, psikolojik veya ekonomik olarak çeker.

34 | P a g e 
Son yaptırım türü ise, dünyada birçok insanı ilgilendiren, dini yaptırımdır. Ruhun ölümsüzlüğüne, öldükten sonra yaşamın devam edeceği başka bir dünyanın var olduğuna, ödüllendiren ve cezalandıran bir Tanrı'ya inanan insan için ahlak ilkelerinin dini bir yaptırım olarak algılanması kaçınılmaz bir durumdur. (Erdem, 2003:95)

Adı geçen yaptırımlardan yalnızca vicdan bireyin içindeki adalet ölçüsüdür. Vicdan her zaman aktiftir ve bilinci uyarır, diğerleri ise; bireyin inisiyatifinde değildir. Sosyal baskı toplumun, doğal yaptırım, anlaşılacağı üzere, doğanın, dinsel yaptırım ise Tanrı'nın inisiyatifindedir.

Din, içerisinde inanç, ibadet ve ahlâk kurallarının yer aldığı ilâhî kaynaklı bir sistemdir. Bu sistem, onu kabul eden birey ve toplumları derinden etkileyerek onların hayatına yön verir, bireyin davranışlarında ve ilişkilerinde belirleyici olur.

Dindarlık ise, bireysel bir tecrübe olduğu için, kesin ve net bir tanımının yapılması oldukça zor görünmektedir. (Aktay vd, 1998:250-272, Yıldız, 2001: 19-42) Bu zorluğa rağmen dindarlık, daha çok yansımaları göz önünde bulundurularak; “insanın inanç ritüel temelinde ortaya koyduğu dinî tutum, deneyim ve davranış biçimini, yani dinî yaşantıyı veya dindar olan bir hayatı; inanılan dinin emir ve yasakları doğrultusunda yaşamayı ifade eden ve inanç, bilgi, tecrübe, duygu, ibadet, etki, organizasyon gibi boyutları olan bir olgu"'(Glock, 1998:253) olarak tanımlanabilir.

Günlük hayatta bazen, dindar birinin, o görüntüsü ile hiç uyuşmayan davranışlarına ya da din ile ilişkisi olmayan ve bunu kendisi de ifade eden birinin, ahlâken çok olumlu tavırlarına tanık oluruz. Burada çözülmesi gereken bir ahlâkî problem var demektir; biri dindar ama ahlâkî sorunları ya da zafiyetleri var, diğeri ise dinî kaygıları yok, ama ahlâkî duyarlılı̆ga sahip.

Ahlak, kişiliğin bilinçli yönüdür. Bilinç ise, akla dayanan bir değerlendirme ve yargı yapma sürecidir. ( Spohn,2000:122-139) Ahlak, bilinçli insanlar arasında ve onlarla ilişkili olarak sergilenen tutumlar hakkındaki bir kararın sonucu olan davranışlarla ilgilenir.(Haynes, 2002:56) İnsan, ahlak öğretiminin nesnesi değil, öznesidir; yani kendi ahlakının yaratıcısıdır. Ahlak, dışarıdan kavratılan, benimsetilen bir şey değil, bireyin içinde oluşan, tıpkı dil gelişimi ve zeka gelişimi gibi, zekaya paralel gelişen bir yapıdır. (Çiftçi, 2000:43-77)

Her ne kadar günlük dilde ahlak ve etik birbiri yerine kullanıllyor olsa da, bu iki terim birbirlerinden farklı anlam taşırlar. Bu noktada etik ahlak ayırımına kısa da olsa değinmek gerekmektedir. Yukarıda da ifade ettiğimiz gibi ahlak, bir halkın, bir toplumun, bir ulusun ya da bir ümmetin belli bir tarihsel dönemde yaşamına giren ve eylemlerini yönlendiren inanç, değer, norm, buyruk ve yasak (Özlem 2010:23) olarak insanların yaşamına yansıyan ilkeler bütünüdür. Yani ahlak yaşanan bir olgudur, belirlenmiş ilkeler bütünüdür. Her insan toplumunda karşılaşılan

değerler toplamı olan ahlak, "İslam ahlakı", "Hıristiyan ahlakı", "Yahudi ahlakı", "Budist ahlakı", "Aristokrat ahlakı", "Türk ahlakı", "Hoşgörü ahlakı” gibi çeşitli şekillerde sınıflandırılabilir. Etik ise ahlaktan farklıdır. Buna göre bireylerin ahlak olarak benimseyip yaşamlarında uyguladıkları ilkeler üzerinde düşünme, sorgulama, rasyonel temellendirme girişiminde bulunma işi etik olarak tanımlanabilir. Yani etik, bir fenomeni ele alıp, ahlak görüşlerini, öğretilerini irdeleyip sınıflandıran, aralarındaki benzerlik ve farklılıkları ortaya koyan, bunları karşılaştırıp eleştiren felsefe disiplininin adıdır. (Özlem, 2010:28) Başka bir ifadeyle etik, ahlak üzerine sistemli bir şekilde düşünme, sorgulama ve tartışmadır. Kısaca ahlak iyi ve kötünün ne olduğunu belirtmekle yetinirken, etik ya da ahlak felsefesi, bir davranışın neden iyi ya da kötü oluşunun kararına nasıl varıldığını inceler. Etik normların eyleme dönüşüp dönüşmemesiyle pek ilgilenmez.

Ahlakın amacı insanı kendi özü ve çevresiyle bir bütünlük içinde mutlu kılmaktır. Amacın mutluluk olduğu anlayışının muhalifleri olmakla birlikte, çoğunlukla bu amaç önemli ahlakçılar tarafından, bazı farklılıklarla birlikte, benimsenmiştir. Örneğin Demokritos, Sokrates, Platon ve Aristoteles'ten itibaren, E. Zekeriya Râzî, Fârâbî, İbn Miskeveyh, İbn Sina, Ebu'l-Hasan el- Mâverdî, Gazâlî, İbn Rüşd, Fahreddin Râzî, Nasireddin Tusî, Yusuf Sinan Paşa, Celaleddin Devvanî, ve Kınalızade Ali Efendi gibi pek çok mütefekkir bu amacı benimsemiştirler. (Platon, 1988:445)

\section{Kohlberg Ahlak Gelișimi Teorisi}

Kohlberg'in ahlak gelişim teorisinin daha iyi anlaşılması için, öncelikle buna zemin hazırlayan ön bilgilere sahip olmak gerekir. Bu amaçla Kohlberg'in hayatını ve ahlak anlayışını inceleyeceğimiz bu başlık altında öncelikle, Kohlberg'in biyografisine kısaca yer vermeye çalışacağız. Ardından, Kohlberg'in ahlak anlayışını; ahlak düşüncesinin temeli, ahlak tanımı, ahlakın kaynağına ilişkin yaklaşımı ve ahlaka ilişkin temel varsayımları çerçevesinde ortaya koymaya çalışacağız.

\section{Hayatı}

Lawrence Kohlberg, 25 Ekim 1927 tarihinde, New York’un Bronxwille bölgesinde doğmuştur. Varlıklı bir Yahudi ailede yetişen Kohlberg, dönemin en ünlü özel okullarından Philips Academy'de okumuştur.

35 I P a g e 
Buradaki lise eğitimini tamamladıktan sonra, askerliğini II. Dünya Savaşı sırasında ticari bir yük gemisinde mühendis olarak yapmıştır. Savaştan sonra, 1948 yılında Chicago'a(Şikago) Üniversitesi psikoloji bölümünde başladığı lisans eğitimini yüksek başarı göstererek, bir yılda tamamlamıştır. Üniversiteyi bitirdikten sonra, klinik psikoloji ya da hukuk alanında çalışmayı düşündüğü sıralarda; İsviçreli gelişim psikologu Jean Piaget'nin çocuk ve ergenlerin ahlaki muhakemesi üzerine yaptığı çalı̧̧ma oldukça ilgisini çekmiştir.(Piaget, 1965:60) Bunun üzerine, lisansüstü eğitim için aynı üniversitede kalarak, bu konu üzerine araştırma ve incelemelerde bulunmuştur. Piaget'nin iki süreçli ahlak gelişim sistemini, ilk çocukluktan olgun yetişkinliğe kadar uzanan altı aşamalı bir sistem halinde geliştirdiği doktora tezini 1958 yılında tamamlamıştır.(Kohlberg, 1986:98) Ardından, Yale ve Şikago Üniversiteleri psikoloji bölümünde öğretim üyesi olarak görev yapmıştır. Daha sonra, 1968 yılında Harvard Graduate School of Education'da çalışmaya başlamıştır. 1971 yılında Orta Amerika, Belize'de gerçekleştirdiği kültürlerarası araştırmaları sırasında tropikal bir hastalığa yakalanmış, hastalığ1 sebebiyle 16 yıl boyunca fiziksel rahatsızlıklarının yanında ağır depresyonla da mücadele etmiştir. 19 Ocak 1987 'de tedavi gördüğü Massachusetts Hospital'dan ayrılmış ve Atlantik okyanusuna atlayarak intihar etmiştir. (Walsh, 2000:37,41)

\section{Kohlberg'in Ahlak Düşüncesinin Temeli}

Ahlakî problemler, farklı talep, çıkar ve değerlerin çatıştı̆̆ adalete dair problemler olup bu problemler aynı zamanda demokrasi problemleridir. Adalete dayanan bir ahlaklılı̆ı temel alan demokratik yaklaşımda bu türden problemler, bütün tarafların perspektiflerinin dikkate alınıp herkes için en adili olabilecek bir çözümün bulunması ile çözülebilir. (Harbach, 1992:48-49)

Kohlberg' in ahlak kavramını adaletle birlikte ele alması lise yıllarına dayanır. Kohlberg'in ahlak ve adaletle ilgili sorgulamaları öncelikle okulda uygulanan kurallara yöneliktir. Okulda uygulanan kuralların gelişigüzel keyfi bir şekilde uygulandığını düşünür. Bu kuralların öğrencilere hak ve adalet bağlamında hiçbir yarar getirmediğini bilakis zarar verdiğgini iddia eder. Bu nedenle de, okul kurallarına dikkate almayan Kohlberg, o yıllarda öğretmenleri tarafindan sigara ve alkol kullanan, yatılı okulda kızlar bölümüne gitmeme gibi kuralları ihlal eden bir öğrenci olarak tanınır. (Gibbs 2014:81-93)

Kohlberg daha sonraları, okuduğu kitaplardaki ahlak konusu hep dikkatini çeker. Örneğin, bir öğretmeninin tavsiyesi üzerine okuduğu Dostoyevski'nin Karamazov Kardeşler adlı kitabındaki ahlaki konulardan, özellikle de Ivan karakterinin dini ve ahlaki sorgulamasından oldukça etkilenir. Ivan'ın, masum insanların, özellikle de çocukların öldürülmesi ve nedenleri üzerine yaptı̆̆ sorgulamalar, Kohlberg'in zihninde ahlaka ilişkin pek çok soru işareti uyandırır. Ancak Kohlberg, sadece okul yaşamına bağlı kalırsa, bu sorularına cevap bulamayacağını ve bunun için okul dışındaki yaşamı da görmesi gerektiğinin farkına varır. Bu için de; çiftlikte çalışmak, arkadaşlarıyla yaz gezileri düzenlemek ve uçak fabrikasında çalışmak gibi yaşantılar edinir. Ancak, lise hayatı boyunca yaptığı ahlaki sorgulamalar, asıl olarak II. Dünya Savaşının ortaya çıkmasıyla daha ciddi bir boyut kazanır. Adolf Hitlerin Yahudi soykırımına yaptığı 1945 sonbaharında Avrupa'ya gidip savaş sonrası durumu bizzat gözlemleme imkanı elde eder ve bu gözlemleri, Kohlberg'in ahlaki fikrinin oluşumunda oldukça etkili olur.(Linn, 2001:339) Özellikle de Yahudi bir babanın oğlu olarak, Nazilerin Yahudi soykırımından oldukça etkilenir ve savaşın görünen yüzünün, sadece yıkım ve korku olmasına rağmen; aslında bunun arka planında tüm dünyanın anlamadığı büyük bir zulüm ve adaletsizliğin yattığına kanaat getirir. (Radest, 2000:60-67)

Savaş sonrası 1947 yılında, Avrupa'da bulunduğu sıralarda, gönüllü mühendis olarak görev yaptığı bir gemideki diğer mürettebatla birlikte, Yahudi mültecileri gemi ambarlarında muz sandıklarına saklayarak, yasadışı olarak Filistin'e kaçırıp İngiliz ablukasından kurtarmaya yardımcı olur. Savaştan geriye evsiz ve yurtsuz kalan bu kimselere karşı adil olmayan bir yasa uygulandığını düşündüğ̈ünden, İngiliz kanunlarına aykırı davranmakta hiçbir ahlaki çelişki ya da pişmanlık yaşamaz. İşte bu tecrübe, Kohlberg'in, ahlaka ve özellikle de adalet kavramına yönelik ilgisinde bir dönüm noktası olur. (Pickren vd, 1988:89-98) Savaş sonrasındaki gözlemleri ve bu yasadışı tehcirle edindiği tecrübeler neticesinde, politik amaçlar uğruna masum insanları ve her şeyden habersiz çocukları öldürmenin, adil olup olmadı ̆̆ı üzerine Kohlberg'in zihninde çok derin ahlaki sorular uyanır. Bu noktada, herkesi kuşatacak, evrensel bir ahlaktan söz edilebilir mi, yoksa kültüre, ya da kişinin şahsi veya hissi duygularına ve politik hedeflerine bağlı olarak ahlak tercihi görecelik arz eder mi, şeklindeki sorularına uzun süre cevap bulmaya çalışır. (Linn, 2001:339)

Üniversite öğrenimine başlayınca, Platon'dan John Dewey'e kadar, ünlü düşünürlerin kitaplarından ahlaki meseleleri okur. John Locke, John Stuart Mill ve Thomas Jefferson'dan yaptı̆g 1 okumalar neticesinde, evrensel insan haklarının ve insan refahının kültüre ya da özel olarak bireye göre rölatif olduğunu düşünmeye başlar; fakat daha sonra bu filozofların görüşlerinin birbiriyle tutarlı olmadığını fark eder. Immanuel Kant'dan yaptığı okumalarla, adalet açısından herkese eşit değer vermenin, her bir

36 | P a g e 
insanın onuruna duyulan saygının, ahlakın özü ve kendisinin de aradığı temel ölçüt olduğu kanaatine ulaşır.

Ancak lisans öğrenimi sırasında yaptığı felsefi araștırmalarla, ahlaki sorularına sadece geçici cevaplar bulduğundan, bununla tatmin olmaz. Bunun üzerine, daha derin bir ahlaki perspektif kazanabilmek için, akademik çalışmalar yapmanın gerekli olduğu kanaatine varır. Lisansüstü psikoloji eğitimi sırasında psikanaliz, hümanistik psikoloji ya da davranışçılık gibi yaklaşımları inceler. Fakat bu yaklaşımlardan da hiçbirinin kişilerin ahlaki problemlerine ve kurumların adalet yapılarına bir şeyler katmada tek başına yeterli olamayacağını düşünür. Daha sonra tanıştı̆̆ Piaget'in çalışmasını temel alarak bilişsel ahlak gelişim yaklaşımını geliştirir ve kendi teorisini ortaya koyar. (Radest, 2000:70-71)

\section{Ahlaki Düşünce ve Ahlaki Yargı Gelişimi Kuramları}

Ahlak gelişimi (moral development) ile ilgili yaklaşım ve çalışmaların tarihsel gelişimine bakıldığında konunun daha çok filozof ve din adamlarının ilgisini çektiği görülmektedir.(Çileli, 1986:27, Aydın 2005:90)) Örneğin, eski Yunan filozoflarından Sokrates, Aristoteles ve Platon toplumun bütün bireylerinin uyabilecekleri ortak bir davranış çizgisi belirlemeye çalışmışlardır. Sonraları din adamları, din kurallarının benimsenmesini hedef alarak konuya çözüm bulmaya yönelmişlerdir. Ancak, toplumsal değişmelerle birlikte otoriter yönetim biçimlerinin, teker teker tarihe karışmaları, statik değer yargılarının, nesilden nesile aktarılmasının, ahlak gelişimi için yeterli olmadığını ortaya koymuştur (Kohlberg, 1976:12-13)

Çocukların ahlak gelişimi konusunda tarihte üç büyük felsefe öğretisi bulunmaktadır. Augustine gibi teologların savunduğu "ilk günah" öğretisine göre; çocuklar doğal olarak günahkar yaratıklardır. Bu nedenle yetişkinlerin müdahalelerine gereksinim vardır. Locke'un başlattığı ikinci görüşs ise çocuğun ahlak açısından yansız olduğunu, eğitim ve yaşantının çocuğu doğru ya da günahkar yapacağını ileri sürmektedir. Rousseau'nun temsil ettiği üçüncü ögretiye göre; çocuklar doğuştan saf ve temiz olduğu ve ahlakdışı davranışları yetişkinlerin bozucu etkisinden kaynaklanmaktadır. (Akboy,1997:89-137)

Ahlak gelişimi ile ilgili ilk bilimsel yaklaşımlar, Freud ve Piaget tarafindan 20. yy başlarında geliştirilmiş, daha sonra da Davranış̧̧ı Psikoloji ve Sosyal Öğrenme Kuramları ile ahlak gelişimi konusuna değinilmiştir.(Erdem, 1995:89) Ahlak gelişimi ile ilgili farklı bilimsel yaklaşımlar bulunmaktadır. Bu yaklaşımlar; "Psikanalitik Yaklaşım", "Sosyal Öğrenme Yaklaşımı", "Bilişsel Gelişim Yaklaşımı"dır. (Demiriz, 2007:105-122)

\section{Psikanalitik Kuramın Ahlak Kavramına Yaklaşımı}

Freud'un (1856-1939) kurucusu olduğu psikanalitik kuram ilk psikolojik ahlak gelişimi kuramıdır. Freud özel bir ahlak gelişimi kuramı geliştirmemiş olmasına rağmen, kişilik gelişimi süreci içerisinde bebeklik ve çocukluk dönemi ilişkilerinin kalıcı özelliğine dikkati çekerek, çocuk yetiştirme teknikleri üzerinde yoğun çalışmalara neden olmuştur.(Aydın, 2005:22-23)Freud, ahlakın doğuştan gelen, içgüdüler ile ilgisi bulunmayan bir sosyal öğrenme problemi olduğunu ortaya koymuştur (Güngör, 2000:93)

Freud ahlak gelişimini id, ego ve süper ego ilişkilerindeki denge kavramına bağlamaktadır. (Dönmezer, 2004:90) İd kalıtımsal olarak gelen, içgüdüleri kapsayan ve doğuştan varolan psikolojik gizil güçlerin tümüdür. (Aydın, 1999:187-203) Ego kişinin çevresiyle etkileşimi sonucu ortaya çıkan kişiliğin gerçekçi, ussal ögesi ve bilinç kısmıdır (Aydın, 1999:188) Bilinç düzeyindeki algılardan, anılardan, düşünce ve duygulardan oluşur. Ego, ruhsal yapının düzenleyicisi, denge ve uyum sağlayıcı öğesidir. (Kağıtçıbaşı, 1998:78) Ego, bir anlamda id'in danışmanıdır, sürekli ona yol gösterir. Kendisine ulaşan ruhsal olayların pek azı, bilinç düzeyine çıkabilir. Bu nedenle, günlük yaşantılarımızın pek çoğunun farkında olmayız. (Senemoğlu,2001:148)

Süper ego çocuğa ana baba tarafindan aktarılan, ödül ve ceza uygulamalarıyla pekiştirilen geleneksel değerlerin ve toplumun ülkülerinin içsel temsilcisidir. Süper ego vicdan ve ideal egoyu içerir, bunun bir kısmı bilinçtedir, diğer bir bölümü bilinçaltıdır.(Gözütok, 2004:102-103) Süper ego, toplum ya da temsilcileri tarafindan onaylanmış ölçütlere göre davranmak ister ve toplumsal yasakları içerir. Davranışların, ahlak kurallarına uygun olup olmadığına karar verir. Freud'a göre anne ile baba çocuğun gelişiminde ilk ve en önemli ahlaki otorite kaynağıdır. (Temel, 2001:67) Ahlak gelişimi, çocuğun kişiliğinde süper egonun gelişmesiyle elde edilmektedir.

Kişilik ve ona paralel olarak ahlak gelişimi belirli psiko-seksüel evrelerden geçerek gerçekleşmekte ve bu gelişim ilk beş yılda tamamlanmakta, altı yaşından sonra önemli bir gelişme görülmemektedir. (Kağıtçıbaşı 1998:80) Süper egonun şekillenmesinde ise, anne ve babanın katı ve sert tutumları, yasaklama ve cezalandırmaları tek yönlü etki yapmakta, sevgiye dayanan tutum ve davranışlar dikkate alınmamaktadır. (Temel vd, 2001:71) 


\section{Sosyal Öğrenme Kuramının Ahlak Kavramına Yaklaşımı}

Sosyal öğrenme kuramcıları ahlak gelişimini, ani hiçbir değişim olmadan derece derece ve sürekli biçimde ilerleyen birikimli bir toplumsallaşma olarak görürler. Bu kuramcılara göre, ahlaksal davranışlar, öteki toplumsal davranışlar gibi pekiştirme, ceza ve gözleme dayalı öğrenme yolu ile kazanılıp öğrenilir. (Güngör,2010:19,117) Bu kuramın en önde gelen temsilcileri Skinner, Eysenck ve Welten'dir. Öğrenme kuramını temsil edenler, ahlak gelişimini incelemek amacı ile vicdan, süper ego ve zihinsel gelişim evreleri gibi soyut yapıları, inceleme ve gözleme olanağı vermedikleri için geçerli olmadığını, ahlak davranışının öğrenilmesinde pekiştiriciler ve gözleme dayalı öğrenmenin gerekli olduğu görüşünü savunmuşlardır.(Çileli, 1986:88) Sosyal öğrenme kuramcıları, çocukların ahlaki değerleri gözlem ve taklit yoluyla öğrendiklerine inanmaktadırlar. Onlara göre çocuklar, diğer insanlarda gördükleri ve kendilerini suça yöneltmeyen davranışları taklit ederler. (Kaya:1997:184-200) Bandura'ya göre öğrenme, hem gözlem, taklit ve pekiştirme süreçlerine hem de probleme özgü durumsal ve çevresel değişkenlerin bilişsel olarak çözümlenmesine bağlıdır. Davranış ve çevre karşlıklı etkileşim halindedir. (Aydın,1993:120) Kohlberg de ahlak gelişiminde taklidin önemli bir olgu olduğunu açıklamakla birlikte, insanlarda görülen ahlaki değerlerdeki değişmelerde bilişsel gelişimin daha önemli olduğunu vurgulamıştır. Ayrıca sosyal öğrenme kuramındaki son gelişmeler, ahlaki gelişmede bilişsel yaklaşımın daha öne çıktı̆̆ını göstermektedir. (Dönmezer, 2004:49) Kısacası, örnek alma süreci içindeki çocuklar, anne-babanın birçok kişilik özelliğini taklit ederken, ahlaki ve kültürel değer ve standartlarını da benimsemektedirler. (Morgan, 1991:110)

\section{Bilişsel Gelişim Kuramının Ahlak Kavramına Yaklaşımı}

Bireyin çevresindeki dünyayı anlama ve öğrenmesini sağlayan, aktif zihinsel faaliyetlerdeki gelişime bilişsel gelişim adı verilmektedir. Bilişsel gelişim; bebeklikten yetişkinliğe kadar, bireyin çevreyi, dünyayı anlama yollarının daha kompleks ve etkili hale gelmesi sürecidir. (Senemoğlu, 2001:234) Bilişsel kuram, ahlak gelişimini zihinsel bir işlev olarak değerlendirmektedir. (Özsöz, 1990:80-82)

Bilişsel gelişim kuramcıları, bilişsel gelişim ile toplumsal deneyimlerin, bireylerin, kural, yasa ve kişiler arası sorumlulukların anlamını daha güçlü bir biçimde kavramalarına yardımcı olduğunu kabul etmektedirler. (Güngör, 2003:108) Ahlak gelişimini bilişsel açıdan ele alan kuramcılar, ahlak gelişimini, farklılıklarla birbirini izleyen evreler olarak kabul etmişlerdir. Diğer bir deyişle bu kuramlar, ahlak gelişimini, bireyin bilişsel gelişimi ile birlikte ele alır. Dolayısıyla, ahlak gelişimi konusundaki çalışmalarda, bireyin zekası, yaratıcılığı, düşünme ve problem çözme becerisi gibi bilişsel süreçlerinin de bu görüş kapsamında incelenmesi gerekmektedir. Çünkü, çocuğun geliştirdiği ahlaki yargı, sosyal çevre ile etkileşimi sonucu doğar ve bilişsel unsurları da baskın şekilde içerir. (Turiel, 1969:65-70)

\section{Kohlberg'in Ahlaki Gelişim Kuramı}

Kohlberg, ahlaki gelişim kuramında, ahlaki yargının, insan yaşamındaki işlevi çerçevesinde incelenmesi gereğini vurgular.

Kohlberg, ahlak gelişimi çalışmasında gerekli ilk adım olarak, "ahlakın" ne olduğunu tanımlamaya önem vermiştir. Kohlberg'in kuramı, en önemli ahlak yapısının "adalet ilkesi” olduğunu ortaya çıkarmıştır. Yani, ahlakın çekirdeği, adalet ilkesine dayanır ve adalet ilkesi kanunların ötesindedir, çünkü yasa ya da sosyal sözleşmelerin beklentileri bu ilke bağlamında en iyi şekilde anlaşılabilir. (Kohlberg,1976:33-47) Ahlaki yargılama yeteneği, birbirleriyle çatışan taleplerin ve değerlerin bulunduğu bir ikilem durumunda, bütün taleplerin perspektiflerinin üstlenilmesi, dikkate alınması ile her bir perspektiften bakıldığında da, en adil görünen çözümün bulunacağ 1 adalet problemlerinde tesbit edilebilir. $\mathrm{Bu}$, ideal rol üstlenme sürecidir. Bu nedenle Kohlberg'in ahlak gelişimi araştırmaları, adalet problemlerinden oluşan farklı değerlerin çatıştığ ikilemler üzerine oturtulmuştur. (Çif̧ci, 2003:43-73)

Kohlberg' in ikilemlerinde, Aristoya dayanan adalet problemlerinin üç biçimi söz konusudur. Bunlar, paylaşım (distributiv), alı̧̧-veriş (kommutatıv) ve düzeltici (korrektiv) adalet problemleridir. Paylaşım adaleti, bir toplum organizasyonu ya da üçüncü kişiye karşı eşitlik, eşit haklar, kazanç, performansbaşarıda ve özel koşullarda onur ve zenginliğin dikkate alınmasıyla/kollanmasıyla ve diğer maddi ya da maddi olmayan kaynakların nasıl paylaşılacağı konusunda çeşitli biçimlerde ortaya çıkar. Alış veriş adaleti, sözleşmelerin yapılması, uzlaşma ve alış-veriş iliş̧kilerini düzenler. Düzeltici/onarıcı adalet, haksız ilişkiler, hırsızlık-dolandırma durumlarında ve tekrar onarma/iyileştirme/düzeltme problemleri söz konusu olduğunda uygulanan adalettir. (Çifçi, 2001:102)

Kohlberg, ahlak evrelerini anlamanın ön şartı olarak, kişilik gelişimindeki ardışık düzeni ve bunun ilerleyişini kavramak gerektiğini ifade etmiştir. Bu duruma göre, insanların gelişim gösterdiği mantık yürütme, sosyal alg1, zeka ve sosyal rol süreçleri iyi incelenmelidir. (Kohlberg 1976:64) Bireyin mantık evresi ile ahlak evresi birbirine paralel ilerler. Ancak, mantık gelişiminin ahlak gelişimi için gerekli bir koşul olmakla beraber yeterli olmadığını belirtmiş ve bunu pek çok bireyin yüksek mantık evresinde

38 | P a g e 
bulunmasına rağmen, daha düşük ahlak evresinde olduğu bulgularıyla desteklemiştir. (Boyes, 1998:4459) Bilişsel gelişim kuramcıları, bilişsel gelişim ile toplumsal deneyimlerin, bireylerin, kural, yasa ve kişiler arası sorumlulukların anlamını daha güçlü bir biçimde kavramalarına yardımcı olduğunu kabul etmektedirler. (Güngör,2010:82) Ahlak gelişimini bilişsel açıdan ele alan kuramcılar,459- ahlak gelişimini, farklılıklarla birbirini izleyen evreler olarak kabul etmişlerdir. (Erden, vd, 2000:91)

“Avrupa'da bir kadın az görülen kanser hastalı̆̆ının bir türü nedeni ile ölmek üzeredir. Aynı kentte bulunan bir eczacının keşfettiği radyumun bir formu olan bir ilaç onu kurtarabilecektir. Eczacı, ilacın maliyetinin 10 kat fazlası olan 2000 dolar fiyat talep etmektedir. Hasta kadının kocası Heinz, tanıdı $\breve{g}$ herkesten borç para alarak ancak 1000 dolar toplayabilir. Heinz eczacıya, karısının ölmek üzere olduğunu söyleyerek, ondan ilacı ya daha ucuza vermesini, ya da paranın yarısını daha sonra vermeyi önerir.

Fakat eczacl, "bu ilacı ben buldum ve para kazanmak istiyorum” der ve Heinz'in önerisini Okabul etmez. Bunun üzerine çaresi kalmayan Heinz, eczaneye gizlice girip, ilacı çalar. Heinz ilacı çalmalı mı idi? Niçin? Eczacı ilacı çok pahalı satmakla doğru mu davranıyordu, niçin? (Kohlberg 1976-127, Kurtunes, vd, 1974:453-470, White, 1999:459-472)

Kohlberg, yukarıda verilen örnek öykü ve benzerleri için aldığı cevapları sınıflayarak, insanların, altı ahlaki yargı evresi geçirdiklerini belirtmiştir. Altı yargı evresini de, üç düzey içinde ele almıştır.

I. Gelenek-öncesi düzey,

*Ceza ve İtaat Eğilimi

*Saf Çıkarcılık (Araçsal İlişkiler Eğilimi)

II. Geleneksel düzey, *İyi Çocuk Eğilimi (Kişilerarası Uyum)

*Kanun ve Düzen Eğilimi

III. Gelenek-ötesi düzey.

*Toplumsal Sözleşme Eğilimi

*Evrensel Ahlak İlkeleri Eğilimi

$\mathrm{Bu}$ düzeylerden her biri, kendinden önceki düzeye dayanmakta ve kendinden sonraki düzey içinde bir temel oluşturur. Yani evreler, hiyerarşik bir bütünleşme içerir.

\section{Düzey I. Gelenek-Öncesi Düzey:}

Bu düzey, Piaget'in "Ahlaki gerçeklik (dışa bağımlılık)” döneminin özelliklerini gösterir ve çocuğun, iyi-kötü, doğru-yanlış konusundaki yargıları, kendisinin yakınında bulunan ve fiziksel üstünlüğe sahip, genellikle anne-baba gibi otoriter kaynaklarına dayanır. (Güngör 2010:106)Bu düzeydeki çocuklar, insan yaşamının değerini, sadece kendi ihtiyaçlarını karşılayacak bir araç olarak görürler ve kendi gereksinimlerini ön planda tutarak, ihtiyaçlarını tatmine yönelirler. Hareketlerinin sonuçlarını görebilme yeteneklerine rağmen, bakış açıları egoistir. (White vd, 1999:462)

1-Ceza ve Boyun Eğme: Bu evrede çocuk, eylemlerinin doğru veya yanlış olup olmadığına, bunların fiziksel sonucuna göre karar verir. Cezalandırıldığı takdirde davranışı yanlış, cezalandırılmadığı takdirde ise, bu davranış doğru olacaktır. Az zarar veren davranış, çok zarar verenden daha iyidir. İki bardak kıran, bir bardak kırana göre daha kötü bir iş yapmıştır. Bu evrede birey, kendisinin merkezi olduğu bir dünyada yaşıyor gibidir. İyi davranış, bireyin istediği ve hoşuna giden davranıştır. Başkalarının da ilgileri ve ihtiyaçları olabileceğini düşünmez. Onların ihtiyaçları ile ilgili değildir. Bu evredeki biri için önemli olan, başının derde girmemesidir. "Yapmamalıyım, çünkü cezalandırılmak istemiyorum”. (Kulaksızoğlu 2004:72)

2. Saf Çıkarcılık: Bu evrede birey, çıkarlarını ön plana alarak, kendi ihtiyaçlarını tatmin eder. İnsan ilişkilerinde "çıkara dayalı alışveriş" söz konusudur. Bu aşamada belirgin düşünce eşitlik olduğu için, "iyilik ya da kötülüklerin karşılıklı eşit paylaşımı” ahlak anlayışının temelini oluşturmaktadır. Doğru olan, kurallara gereksinimleri karşıladıkları sürece uymak, ihtiyaca dayalı adil değiş tokuşlar ve anlaşmalar yapmaktır. Her şey karşılıklıdır. (Çileli 1981:60)Doğruyu yapma nedeni, kendi gereksinim ve çıkarlarına hizmet etmektir. Öyleyse bu evreye "araçsal amaç evresi" de denilebilir. (Yapıcı vd, 2005:132)

Bu evreye uygun örnekler şunlar olabilir. (Atıcı vd, 2004:223)

"Senin kamyonunla oynamama izin verirsen, sana bisikletimi ödünç vereceğim."

"Eğer bu akşamki filmi izlememe izin verirsen ben de ödevlerimi şimdi yapacağım". 
Düzey II. Geleneksel Ahlak Düzeyi:

Bu düzeydeki birey, gelenek öncesi düzeyin egoist bakış açısından, grup değerlerini ve kurallarını bilişsel açıdan tanıma düzeyine geçiş yapar. Birey, kişiler arası iyi ilişkiler kurma eğilimine yönelir. (Ersoy 1997:81)

Geleneksel düzeyde diğer insanlar tarafından kabul edilen, benimsenen ve takdir edilen davranıșlar doğrudur. Bu düzeydeki birey, ailesinin, grubunun ya da milletinin beklentilerini kendi doğruları olarak kabul eder. Birey, yalnızca, toplumun veya otoritenin kurallarına, beklentilerine, geleneklerine uymakla kalmaz aynı zamanda, bu düzeydeki kuralları destekler, haklı görür ve kurallara sadakat gösterir. $\mathrm{Bu}$ noktada, yalnız toplumsal düzene uymak değil, bu düzeni korumak, desteklemek ve bu düzenin kurum ve gruplarıyla özdeşleşmek de önem kazanır. (Çileli 1986:65)

3-İyi Çocuk Eğilimi (Kişilerarası Uyum): Bu evrede iyi davranış, başkalarını memnun eden, onlara yardımcı olan ya da onlar tarafından takdir edilen davranışlardır. İyi olmak; başkaları ve onların duyguları ile ilgilenmek, karşılıklı ilişkileri sürdürmek, sadık ve güvenilir olmak, minnettarlı̆ğ sürdürmek, beklentiler ve kurallar doğrultusunda davranmaktır. İyi olmanın yanında, diğer insanlarla olumlu ilişkileri destekleyen kuralların ve otoritenin devamlılı̆̆ını sağlamak da önemli görülür. Davranışlar, ilk defa niyete göre değerlendirilmeye başlanır. İkinci evredeki "mutlak eşitlik" yerini "adalet" anlayışına bırakır ve dolayısıyla üçüncü evredeki bir birey, hem kendi gözünde, hem de başkalarının gözünde iyi bir insan olma gereksinimi hisseder ve kendini başkalarının yerine koyarak iyi davranılmayı bekler. Başkalarınca sevilmemek ve onaylanmamak kaçınılması gereken bir davranış biçimdir.

(Kulaksizoğlu, 2001; Ersoy, 1997).

4-Kanun ve Düzen Eğilimi(Vicdan): Bu evrede ahlak, paylaşılan standartları, hakları ve sorumlulukları benimseme ve yerine getirme olarak tanımlanır. Birey için doğru davranma, toplumsal düzeni korumak, toplumun ve grubun refahı doğrultusunda davranmaktır. Bu evrede kanunların korunması, bağlı olunan kurum, grup veya topluma katkıda bulunmak ve başkalarının beklentilerine saygı duymak gerekli görülür. Bu yönde davranmanın gerekçesi, bir bütün olarak toplumun sürekliliğini sağlamak, "herkes yaparsa ben neden yapmayayım?" mantığı ile sistemden doğabilecek bozulmalardan sakınmak ve toplumun ön gördüğü sorumlulukları yerine getirmek için, kendini vicdanen sorumlu hissetmektir (Adams, 1995; Kulaksizoğlu, 2001)

Bu evrede, gruba bağllık, kişisel ilişkiler ve iyi niyet tek başına yeterli değildir. Birey, yasaların toplumun iyiliği için var olduğunu bilir ve kendi huzuru için yasalara katı bir biçimde bağlanır. Her yasanın, istisna göstermeksizin herkese aynı şekilde uygulanmasının eşitlik ilkesinin temelini oluşturduğunu kabul eder (Kulaksızoğlu, 2001).

\section{Düzey III. Gelenek-Ötesi (ilkeli):}

$\mathrm{Bu}$ düzeyde, insan yaşamı, kutsal ve evrensel bir doğru olarak algılanır ve insan haklarının gözetildiği evrensel değerler benimsenir. Bu düzeyde birey, ahlaki otonomiyi geliştirir ve diğerlerinin doğrularına saldırmaktan kaçınır (White ve Richard, 1999).

5-Toplumsal Sözleşme Eğilimi: Kişi, adaletli olmayan yasalara boyun eğme yerine, bunları değiştirmeyi doğru bulur. Yasaların çoğunluğunun, insan haklarını korumak için yapıldıklarını kabul etmekle birlikte, işlevsiz ya da yetersiz olan ve insan haklarını korumakta aciz olan yasaların değiştirilebileceğine inanır. Bu evredeki birey, başkalarının haklarını çiğnemekten kaçınır. (Hoffman, 1970; Kulaksizoğlu, 2001)

6-Evrensel Ahlak İlkesi: Beşinci evrede, iyi bir topluma sahip olmak için, temel bireysel hakları korumak ve demokratik süreçlerle anlaşmazlıkları bir karara bağlamak gereksinimine dikkat çekilirken, Kohlberg, demokratik süreçlerin tek başlarına "adaletli" sonuçlar doğuramayacağını belirtmiş ve daha ileri bir evre olması gerektiğine inanmıştır (Boyes,1988). İnsanlara karşı tarafsız bir saygı tutumunu ifade eden ahlaki tavrı temsil etmektedir. Bu saygı, konuşmalar ve ideal rol üstlenmeye dayanan diğer etkileşim biçimleri aracıllğı ile gösterilmelidir. İdeal rol üstlenme ahlaki çatışmalarda karmaşa içindeki kişilerin temsil ettiği çeşitli talep ve pozisyonların dikkate alınmasına yol açmaktadır. (Çiftçi 2000:60)

$\mathrm{Bu}$ ileri evrede, doğru ve yanlış, sosyal düzenin yasa ve kurallarıyla değil, kişinin kendi vicdanıyla ve kendi geliştirdiği ahlak ilkeleriyle tanımlanır. Bu ilkeler, somut ahlak kuralları olmayıp, genel soyut ilkelerdir. Bu ilkeler, evrensel adalet ilkelerini, insan haklarının eşitliğini ve bireysel bir kişi olarak insanın onuruna duyulan saygıyı içermektedir. İnsanlar, araç değil, amaçtırlar. Ahlaki prensipler, kurallardan farklıdır. Kurallar özeldir, ahlaki prensipler geneldir. En önemli ahlaki prensip; adalet, eşitlik

40 | P a g e 
ve başka insanların haklarını korumaktır. $\mathrm{Bu}$ prensipler herhangi bir yasadan daha önemlidirler.(Kağıtçıbaşı 1996:50, Kulaksızoğlu 2001:76).

Kohlberg'in ahlaki gelişim kuramını kısaca özetleyecek olursak, birinci düzeyde, gerçek anlamda bir ahlak anlayışı yoktur. Çocuk, benmerkezci bir eğilim içindedir; bencil güdülerine doyum sağlayacak davranışlarda bulunmak ister, otoriteye saygı gösterir ve insanları nesne olarak görür. İkinci düzeyde olan "yasa ve düzen" evresinde ise, ahlaki ikilemler, toplumsal beklentiler ve geleneksel kurallar dikkate alınarak çözümlenir. Bu dönemde, iyi çocuk olmak önemle vurgulanmaktadır. Ahlakgelişiminin üçüncü düzeyinde ise, birey yargılarını sadece belirli yasal kurallara göre değil, soyut evrensel ahlak ilkelerine dayandırma eğilimi gösterir (Morgan, 1991:21).

Kohlberg' in kuramında yer alan bu üç ahlaki gelişim düzeyi, ahlak gelişiminin kapsamını belirler. Birinci düzey, genellikle çocukların düşünce biçimlerini betimler, ancak bazı ergenlerin, yetişkin ve yetişkin suçluların bu düzeyde oldukları gözlemlenmiştir. İkinci düzey olan geleneksel düzey, genellikle erinlikte görülmeye başlanır, ergenlikte tam olarak benimsenir. Yetişkinlerin birçoğu, geleneksel düzeydedir. Gelenek ötesi düzey ise, en az rastlanan düzeydir, eğer ortaya çıkarsa ergenlikten başlayarak ilk yetişkinlikte görülebilir ve çok az yetişkinin ulaşabildiği düzeydir. Kolberg'e göre bu düzey, Martin Luther King, Mahatma Gandhi ve Rahibe Terasa gibi seçkin insanların bulunduğu bir düzeydir (Güngör 2003:85).

Kohlberg'e göre, bir bireyin sosyal bir gruba ya da kuruma katılımı ne kadar yüksekse, başkalarının sosyal perspektiflerini takınma olanağı da o oranda fazlalaşmaktadır. Rol almanın yetersiz kaldığ 1 sosyokültürel koşullar altında, ileri evrelerin gelişmesi beklenmemektedir. Kohlberg, bireyin toplumsal algısının ve toplumsal bilincinin, ahlaki yargı yetisi çerçevesinde oluştuğunu öne sürmektedir. Ahlaki mantık yürütme gelişiminin, evrensel ve değişmez bir ardışılıkta tüm kültürlerde gözlenebileceğini belirtmiştir.(Carpendale 2000:181-205) Kohlberg'e göre, bütün kültürlerdeki insanlar, adalet, demokrasi, merhamet, dürüstlük, dindarlık, iyilikseverlik, hayırseverlik eşitlik, saygı, özgürlük, vatandaşlık hakları gibi aynı temel ahlaki kavramları kullanırlar ve kültür farkına bakmaksızın, bütün bireyler, akıl yürütme evrelerinden geçmektedirler. (Verhoef, 1997:389-407)

\section{Dinlerin Hedeflediği İdeal İnsan}

Dinler, mensuplarından, Tanrı'nın hoşuna gidebileceğine inandıkları bazı kült davranışları bekledikleri gibi, sosyal ve tabii çevreye zarar vermeyecek, toplumsal huzuru ve güzelliği koruyacak davranışlar da beklerler. Bu tarz davranışlar ise hem bu dünyada hem öteki âlemde kişiyi mutlu edebilecek hareketlerdir. Ahlaki davranışlar da diyebileceğimiz bu unsurlar, tüm dinlerin ortak yönünü oluşturmaktadır. $\mathrm{Bu}$ davranışlardan olumlu olanlar kabul görmüşken, yanlış olanlar, reddedilmiştir. (Sarıkçığlu, 2002:131) İnsan, yalnız biyolojik ihtiyaçları olan, yiyip içen, uyuyan ve sadece bu dünya için yaratılmış bir varlık değildir. İnsan, kendisini oluşturan maddeler bakımından basit olarak görülse de kendisine yapılan manevi katkılarla komple bir varlık olması nedeniyle diğer canlılardan farklıdır. İlahi dinlere göre insan, topraktan yaratılmış, Allah'ın kendisine üflediği ruh ile değer kazanmıştır. Fiziki yönden ana maddesi olan toprağın özellikleri insanın bütün yapısında yer almıştır. Bugünkü ilmi gerçekler, insan bedeninin tamamının, toprağın oluşturduğu; bakır, demir, oksijen, hidrojen, kalsiyum, potasyum, kireç ve sodyum gibi elementlerin meydana getirdiğini ortaya koymaktadır. (Hicr 15:28-29, Öztürk, 2004:17)

İnsan temelde asli tabiat, kalp ve akıl olarak üç öğeden oluşmuştur. Bunların her birinin, insan tutum ve davranışları üzerindeki pek çok etkisi vardır. İnsan tabiatında bazı değişim ve gelişmeler mümkün görülse de yine de henüz tam olarak anlaşılmış değildir. (Aydın 1999:26-30) Bazen insan, kendini dahi anlamakta zorluk çekmektedir. Bu durum insanın değişik zamanlarda sergilediği davranışlardaki farklılık göz önüne alındığında daha iyi anlaşılacaktır. Dolayısıyla kişinin bizzat kendisi de ne zaman, nerede, nasıl davranacağını tahmin edememektedir. Zira insanın iç dünyası, ardı arkası kesilmeyen değişiklikler içindedir. İnsanlar, bazen değerler ve davranışları birbirine uyduramamaktan kaynaklanan sıkıntılar yaşarlar. Bu, insanın iç âlemini ve kendisini yeterince bilememesinden kaynaklanır. Bu parçalanmışlı̆̆ sona erdirmek için fikir mücadelesine ve gerekli enerjiye sahip olanlar ise ancak bu ikilemden rahatça kurtulabilirler. İnsan fiillerinin nitelik kazanmasında, kişinin irade hürriyetine sahip olması önemlidir. İrade olmayınca, kudret başlı başına hareketi meydana getirmez. Acizlik halinde insan, nötr durumdadır. Hiçbir şey yapmaya gücü yoktur. Fiilin oluşması için önce irade sonra kudret gereklidir. (Sert, 2004:31) İnsan, kendi tabiatına uygun davranışlar üretir ve bu davranışlara uygun bir vicdan oluşturur.(Hökelekli, 1998:85) Bunlar, davranışlarımızın farklılaşarak çeşitlenmesine sebep olmaktadır. Hayatta karşılaşılan çeşitli problemler insanı öyle kuşatır ki çatışması olmayan kişilere kolay kolay rastlanmaz. Çünkü insan, çelişkilerle dolu bir varlıktır. Bunun adı İslam'a göre nefstir. Zira Gazali’ye göre nefsin bir bedene, diğeri ruhani âleme bakan iki yönü bulunmaktadır. Dolayısıyla zıt eğilimler aynı anda etkin durumdadırlar. (ElMaverdi,1978:38-44) Nefs, insanın iç benliği bütün insani yaşantıların oluştuğu psikolojik alandır. Bu zıt eğilimlerin önünde nefs, kendi varlığında kendi kendisini düzenleyici ve dengeleyici bir sistem, (Şems

$41 \mid \mathrm{P}$ a g e 
91:9-10) gelişme ve olgunlaşmaya kabiliyetli dinamik bir gücü sağlamaktadır. Ancak, Kur'an'ın ifadesiyle insan istikrarsız, değişken, zayıf, hırslı ve huysuz bir tabiata sahiptir. (Nisa 4:128, Mearic 70:19-21) İşte bu, nefiste bulunan dürtü ve eğilimler, davranış1 etkilemektedir. (Al-i İmran 3:14, Kehf 18:34) Dolayısıyla insan kolayca bunların büyüsüne kapılabilmektedir. İnsanlık tarihini ilk anlarından beri insanlar, zaman zaman nefsinin yanlış isteklerine uymuş ve fitratlarına konulmuş olan din duygusuna rağmen hatalar yapmıştır. İnsanlığın atası kabul edilen Hz. Adem, yaptığı hatayı anlamış tövbe yolunu seçmiştir. O’nun oğulları, Habil ve Kabil arasında da nefse uyma sonucu, yanlış davranışlar meydana gelmiştir. Nitekim bir ayette bu konu şöyle dile getirilmiştir: "Onlara Âdem' in iki oğlunun haberini gerçek olarak oku: Hani birer kurban takdim etmişlerdi de birisinden kabul edilmiş diğerinden ise kabul edilmemişti. Kabul edilmeyen kardeş: Andolsun 'seni öldüreceğim' dedi. Diğeri de: 'Allah, ancak sakınanlardan kabul eder' dedi..." (Maide 5:27) Her ne kadar Tevrat ya da Kur'an'da Habil' in kurbanının kabul ediliş şekli yazmıyorsa da özellikle İslam kaynaklarında, gökten gelen bir ateşin, Habil'in kurbanının yakıp yok ettiği, dolayısıyla da kabul edilenin o olduğu kanaati yer almaktadır. (Güç 2003:18) Ancak konumuz açısından önemli olan Kabil'in daha sonraki davranışıdır. Buradan da anlaşılıyor ki Kabil, Habil'i gerek kıskançlıktan ve öfkeden, gerekse insanda var olan beğenilme dürtüsünden dolayı öldürmüştür. Aynı şekilde Yusuf Peygamber de kardeşlerinin kıskançlığından ötürü pek çok sıkıntı yaşamıştır. (Yusuf, 12:10-18)

\section{Yahudiliğe Göre İdeal İnsan}

Dinler ilahi kaynaklı olsun ya da olmasın her din belli bir öz, bir katı çekirdek etrafında şekillenmiştir. Her dini birbirinden ayıran belli başlı temel unsurlar vardır. Ve bu unsurlar o dindeki inanç, ibadet ve ahlak esaslarının oluşmasında önemli bir etkiye sahiptir. Bu bağlamda ele alındığında Yahudiliği de diğer dinlerden ayıran en önemli unsurlar; seçilmiş ırk/halk düşüncesi, vaad edilmiş toprak ya da mabed inancı, Mesih ve tek Tanrı anlayışıdır. (Tillich, 2014:31, Faruki, 2011:68-70, Aydın,2004:10-14)

Yahudi ahlakı Tanrısal ve toplumsal olmak üzere iki boyutludur. Yahudilik'te ahlakın Tanrısal boyutu tek Tanrı inancına dayalıdır. Mevcut ahlak ilkeleri de bu ilke etrafında şekillenmiştir. Tevrat'ta yer alan "Tanrınız Rab'bi bütün yüreğinizle, bütün canınızla, bütün gücünüzle seveceksiniz... Tanrınız Rab'bi sevip, yolunda yürüyeceksiniz..." ifadesi insanın nasıl bir yol takip etmesi gerektiğine işaret eder. Tevrat'a göre insan ahlaki olarak olgunluğa, mükemmelliğe ancak Tanrı'nın yolundan giderek ulaşabilir. (Yasa'nın Tekrarı, 6:4-5, 11:22)

Yahudilik'te dünya hayatındaki düzenin ve barışın sağlanması, korunması, huzurun oluşturulması ancak Tanrının emir ve buyruklarına uymakla mümkündür. Tevrat, Yahudiler için dini ve ahlaki kuralların temel kaynağıdır. Yahudiler kendilerini Allah ile anlaşma yapmış bir millet olarak görmektedirler. (Aydın 2007:5) Eski Ahit'te yer alan Tanrı'nın Sina Dağı'nda halkıyla yaptığı anlaşma Yahudilerin yaşamlarına 1şık tutacak bir tarzdadır. Bu anlaşma öncelikli olarak ahlaksal yasaları içermektedir. Bunun yanı sıra bu anlaşmanın içinde yine toplumda düzeni sağlayacak toplumsal ve sosyal yasalar ve ilkeler de yer almaktadır. (Mısır'dan Çıkış 56) Yahudiler bu anlaşma ile kendilerini seçilmiş ırk olarak kabul etmektedirler.(Aydın 2004:10-11) Yahudilere göre Tanrı çocukları arasından kendilerini seçmiş ve onları "goyim" diye nitelendirdikleri Yahudi olmayanlardan üstün kılmıştır. (Faruki, 2011:71-72)

Yahudi ahlakının temel esaslarını oluşturan Tanrı ile Sina Dağı'nda yaptıkları ahitleşmede Musa'ya verildiğine inanılan "On Emir"dir. On Emir şunlardır:

1.Benden başka Tanrın olmayacak.

2.Kendine yukarıda gökyüzünde, aşağıda yeryüzünde ya da yer altındaki sularda yaşayan her hangi bir canlıya benzer put yapmayacaksın. Putların önünde eğilmeyecek, onlara tapmayacaksın.

3.Tanrı'n Rab'bin adını ağzına boş yere almayacaksın. Çünkü Rab adını boş yere ağıza alanları cezasız birakmayacaktır.

4.Şabat Günü'nü kutsal sayarak anımsa. Altı gün çalışarak bütün işlerini yapacaksın. Ama yedinci gün bana, Tanrı'n Rab'be Şabat Günü olarak adanmıştır. O gün hiçbiriniz hiçbir iş yapmayacaksınız.

5.Annene babana saygı göstereceksin.

6.Adam öldürmeyeceksin.

7.Zina etmeyeceksin.

8.Çalmayacaksın.

9.Komşuna karşı yalan yere tanıklık etmeyeceksin.

10.Komşunun evine, karısına, erkek ve kadın kölesine, öküzüne, eşeğine, hiçbir şeyine göz dikmeyeceksin. (Mısır'dan Çıkış, 20:2-17)

Yahudi ahlakının temel taşlarını oluşturan bu On Emir iki levha şeklinde Musa'ya verilmiştir. İlk levhada yer alan dört emir insanın Tanrı Yahve'ye karşı olan sorumluluklarını belirtmektedir. İnsan önce Tanrı'ya karşı olan sorumluluğunu yerine getirmeli ve O'na benzemeye çalışmalıdır. Yahudilik'te insan Tanrı suretinde olduğu için bu insanın ahlaki mükemmelliğine ulaşmasında gerekmektedir.

42 | P a g e 
İkinci levhada yer alan altı emir ise insanların birbirlerine karşı olan görev ve sorumluluklarını göstermektedir. İnsanlar bu sorumlulukları yerine getirdiğinde ahlaki yasaya uygun davranmış olmaktadır. Bu ahlaki yasalar doğrultusunda da toplumda düzen ve huzur ortamı oluşmakta ve bu ortam devamlılı̆ını korumaktadır.

On Emir'in yanı sıra yine Eski Ahit'te birçok ahlak kuralı yer almaktadır. Sadece Eski Ahit'te 613 ahlak kuralı olduğu belirlenmiştir. (Faruki, 2011:45) Bunların içinde "şiddete karşı yasalar", "mala ilişsin yasalar", "adalet ve doğruluk yasaları" gibi ahlaki yasalar yer almaktadır. (Mısır'dan Çıkış 21,22,23)

Eski Ahit'te "Süleyman'ın özdeyişleri" başlıklı kısımda ahlaki birçok ilkeye de yer verilmiştir. (Süleyman'ın özdeyişleri, 22,23)

Merkezinde tek Tanrı inancı olan Yahudilik'te temel olan esas mensuplarına ahlaki bir kişilik kazandırarak, ideal insan tipini oluşturmaktadır. Yahudi ahlakının temelini Tanrı'nın buyruk ve emirlerine riayet etme teşkil eder. Ahlaki ilkeler Tanrı kaynaklı olduğu için ilahi temellidir.

Yahudilik'te toplumsal huzur, güven ve mutluluğun temini için ahlak ve değer ilkelerinin ön plana çıkarıldığı görülmektedir.

Yahudi ahlakı ilk başlangıçta tek Tanrı anlayışına dayalı bir biçimde ilahi kaynaklı olarak şekillenmiştir. Ancak Yahudiler ahlaki temellerin de üzerine oturduğu seçilmişliği sorumluluk ve görevden ziyade üstünlük/ üstün ırk olarak algılamışlardır. Seçilmişlik anlayışı Yahudi ırkçılığına dönüşmüştür. Bu alg1 da Yahudi ahlak ilkelerine yansımış ve ahlaka pek uygun olmayan birtakım tutum ve davranışların önünü açmıştır. (Faruki, 2011:79-82) Öyle ki Yahudiler On Emiri Yahudi ırkıyla sınırlamışlar, Yahudi olmayanları ise Nuh Yasaları ile sorumlu tutmuşlar ve onları ötekileştirmişlerdir.

Bu rkç̧ılı̆ın ortaya çıkmasıyla ahlak ilkeleriyle tezatlık oluşturan bir kısım ve davranışları Yahudi halkının yapmasını müsamaha gösterilirken, aynı şeyleri Yahudi olmayanların yapması yasaklanmıştır. Örneğin; ilk olarak On Emir'de "çalmayacaksın" diye Yahudilere yönelik ahlak ve toplumsal bir ilke yer almaktadır. (Mısır'dan Çıkış, 20:15) Yine Yahudilerin Kutsal Kitabında yer alan diğer bir buyruk ise şöyledir: "Halkımın Mısırlıların gözünde lütuf bulmasını sağlayacağım. Gittiğinizde eli boş gitmeyeceksiniz. Her kadın Mısırlı komşusundan ya da konuğundan altın ve gümüş takılar, giysiler isteyecek. Oğullarınızı ve kızlarınızı bunlarla süsleyeceksiniz. Mısırlıları soyacaksınız." (Mısır'dan Çıkış, 3:21-22) Bu buyrukla Yahudi olmayanların mallarını soymaya teşvik edildiği görülmektedir. Bu hem On Emir'de yer alan "çalmayacaksın" ilkesine ters olup hem de "mala ilişkin yasalar" da yer alan ilkelere tezattır. (Mısır'dan Çıkış, 22)

\section{Huristiyanlığa göre İdeal İnsan}

Hristiyanlık'ta İsa Mesih etrafinda şekillenmiş, inanç, ibadet ve ahlak esasları da İsa temelli olarak oluşmuştur. İsa, Yahudi bir erkek olarak Yahudi bir bölgede dünyaya gelmiştir.(Gündüz, 2013:16) Geldiği dönem ve içinde yaşadığı ortamda Yahudilerle birlikte olan İsa sürekli olarak Yahudileri gözlemlemiştir. Onların Kutsal Kitap'ı Tevrat'a ve tüm ahlaki ve manevi ilkelerine aşina olmuştur. Bu ilkeleri inceleyen İsa bunların hatalarını keşfetmekten de öteye geçerek insanın ahlaki bilincini yeterince dikkate alan bütüncül bir ahlak ortaya koymuştur.

İsa'nın istediği yeni ahlak, Yahudi ahlakının sahip olduğu üstün ırk/ seçilmiş ırk anlayışının aksine içsel benlik ve birey etrafinda oluşturulmuş, hem yüksek ahlak değerlerini hem de tüm insanlığı kucaklama işlevini gerçekleştiren bir ahlak anlayışıdır. Bu yüzden İsa Yahudi ayrımcılı̆̆ı, dışlayıcı ve ırkçılığına karşı insanların evrensel kardeşliğini ilan etmiştir. (Faruki, 2011:97,114)

Hıristiyan geleneğine göre İsa Mesih'in "Dağ Vaazı" olarak bilinen deyişleri Hıristiyan ahlakının temel özelliklerini içermektedir. İsa "Dağ Vaazı"ndaki sözleri ve konuşmasıyla, ileride kurulacak olan Hıristiyan toplum ahlakının da temellerini atmıştır. (Çetin, 2015:40) İsa'nın Dağdaki Vaazı'nda, maddeleşmiş, bencilleşmiş ve zalimleşmiş Yahudi toplumu içinde, mütevazı, ahlakl, merhametli, gönlünü mala ve mülke teslim etmeyen, ruhen temiz bir toplum meydana getirmeyi hedeflenmiştir. Bunun için İsa kendisini İsrail'in kaybolmuş koyunlarını gütmeye gelmiş olarak nitelendirmiştir. Bu nitelendirme Yeni Ahit'te şöyle geçmektedir: "... Ben yalnız İsrail halkının kaybolmuş koyunlarına gönderildim..." (Matta, 15:24)

İsa'nın ahlakı gerçek bir niyet ahlakıdır. O yararlılığı arka plana atmış, eylemin sonucuna değil, niyetine önem vermiştir. Failin fiilen gerçekleştirdiği sonuç, yararlılık kuralı açısında iyi de kötü de olabilir. Ancak eyleme ahlaki karakterini kazandıran, niyettir. İşte İsa, bu yeni ahlak ile Yahudi bilinciyle mücadele etmiştir.

\section{Budizm, Hinduizm Ve Konfüçyanizm'de İdeal İnsan}

Bugün dünyanın pek çok ülkesinde yaşanan ve beş yüz milyondan fazla müntesibi bulunan Budizm, (Kaya, 1999: 30) herhangi bir Tanrı inancına sahip değildir. Budha (M.Ö. 563-483) ne Tanrı'ya inanmış ne de böyle bir şeyi takipçilerine telkin etmiştir. (King, 2001: 17, 18) Hatta Budha'nın öğretisinde ruh ve 
öteki dünya gibi kavramlara da yer yoktur. Budizm'e benzer dinlerde sayısız doğuşlarla sonsuzluk ileri sürülürken, Budha, her şeyin geçici olduğunu söyleyerek, bunun tersini savunmuştur. Ona göre her şey sonsuz bir değişim içindedir. Ancak burada temel koşul nedensellik ilkesidir. Her şey birbirini doğuran fenomenler zinciriyle meydana gelir. Neden ve sonuç birbirine hiç benzemeyebilir ve bir sonucun birden fazla nedeni olabilir. (Kaya, 1999: 17, 19, 20) Tanr1, ruh, sihir, büyü, özetle, metafizik problemlerle uğraşmayan Budha'nın düşünce sistemi, dinsel bir düzen ve din olarak kabul edilmekle birlikte, aslında Budha'nın Tanrı'dan bahsetmeyerek, yalnızca kendi düşüncelerini ortaya koyması, onun bir etik kurucu olarak değerlendirilmesine izin verebilir. Onun kurduğu ve din olarak değerlendirilen sistem, insanı ve toplumu, doğanın acımasız düzeninden çıkarıp sosyal bir varlık olarak, birbirini incitmeden yaşamanın yolunu göstermeye çalışmıştır. Budizm, rrk, ülke ve sınıf ayrımı gözetmeyen, bütün canlılara merhametle bakan, yani göksel dinler gibi evrensellik iddiasında bulunan bir yaşam felsefesidir. Budha'nın düşünceleri iki bin beş yüz yıldır yaşamaktadır. (Kaya; 1999: 17, 18, 31, 32)

Hinduizm de aynı şekilde, insanın kendisi için hiçbir şey yapmaması, devamlı başkalarını düşünmesi 'ego'sunu hemen hemen yok etmesi gerektiği öğ̈̈tlenmektedir. (Coomaraswamy, 2000: 32, 33) Bu öğreti de, Budizm'de olduğu gibi, 'kötü'lüğün neredeyse yok edilmesi gerektiği, sürekli iyiliğin salık verildiği bir öğretidir.

Budizm'deki Nirvana'ya ulaşma çabası bu dünyayla ilgilidir. 'Saf iyilik' olarak tanımlanabilecek nirvanaya insan öldükten sonra değil, bu dünyada yani yaşarken ulaşır. Nirvana'ya ulaşmış insan ise artık 'salt iyi' haline gelmiştir; istek, nefret, cehalet, gurur, rekabet duygusu, bencillik, aşırılık duygusu, kötülüğge neden olan aşırı cinsellik arzusu vb'nden tamamen uzaktır; saf, nezaketli, merhametli, hoşgörülü ve özgecidir. (Kaya, 1999: 24-26) Nirvana'ya ulaşamamış bedenin dünyaya yeniden gelmesi, yani yeniden yaşam, onun için acı veren büyük ve zahmetli bir yüktür. Budha yaşamdaki asıl amacın bu acıdan kurtulmak olduğunu ileri sürer; bunun için izlenmesi gereken yolu ve kuralları açıklar. İşte bu yol erdem, adalet, hak, hukuk ve Budha'nın özgeciliği öğreten diğer bütün prensipleridir. Bunu yapmak için ılımlı olmak (orta yol), hırs ve tutkudan uzak, duyguların azdırdığ uzak bir yaşam tarzını benimsemek gerekir. (Kaya, 1999: 21, 22)

Budha'nın ortaya koyduğu prensiplerin bazılarını daha buraya almak, konunun daha iyi anlaşılmasını sağlayacaktır.

"Hiç kötülük işleme, iyilik yap ve kendi düşünceni temizle", "kimseyi azarlama, kimseye vurma, kanunun sınırları içinde davran", "gökten altın yağsa, insanın isteği doyurulamaz; isteğin küçük bir zevk verdiğini ve aslında acıya neden olduğunu bilen kişi, bilge bir kişidir." (Kaya; 1999: 103, 104) "İyiliği aramada ısrarlı olan ve huzura kavuşmayı isteyen kişi, becerikli, vicdanı duyarlı, nezaketli konuşan, alçak gönüllü biri olmalıdır." (Kaya, 1999: 147) "Bizden nefret edenlerden nefret etmeden yaşayalım", "galibiyet nefreti doğurur, çünkü yenilen kişi mutsuzdur; galibiyeti de yenilgiyi de terk eden kişi huzur içindedir", "kişi öfkeyi sevgi ile, kötülüğü iyilikle yenmelidir; açgözlülüğü cömertlikle, yalanı gerçekle yenmelidir", "bedeninizin, dilinizin ve aklınızın öfkesinden kurtulun; bedeninizle, dilinizle ve aklınızla erdemli olmaya çalışın.” (Kaya, 1999: 105, 108, 109)

$\mathrm{Bu}$ prensiplerden çıkarılacak sonuç, dikkat edilirse, Budizm'in temel amacı olan 'ego'nun yok edilmesine (Bachelor-Brown, 1997: 65, 66) yöneliktir.

Öyleyse bütün bu diğerkamlığı öngören prensiplerin hayatiyet kazanması, başka bir ifade ile yaptırımı nedir?

Her şeyden önce, etik'te önemli bir problem olan, yapılacak eylemlerin sonuçlarını dikkate alıp almama konusunda Budizm, Kant'ın ödev ahlakını çağrıştıran bir yaklaşımla, sonuçların dikkate alınmamasını, ödevin ödev olarak algılanıp, sonuçta fayda ya da zarar verip vermeyeceğinin hesabı yapılmaksızın sadece yerine getirilmesini istemektedir. Budizm'e göre bu öğretiye bağlı olanlar eylemde bulunurken, amaç olarak tam bir iç objektifliğe sahip olma çabası içinde olmalıdırlar. Yapılacak bir iş, yerine getirilecek bir görev veya uygulanması gereken bir prensip varsa, birey bunu yaparken, yani eylemde bulunurken sonuçların dikkate almayacak, tarafsız olacaktır. (King, 2001: 91, 92)

Ancak, yaşama içgüdüsüyle egosu öne çıkan insanın, faydayı gözetme eğilimi, yalnızca 'yapacağın eylemin sonuçlarını dikkate alma' denilerek giderilebilir mi? Elbette herhangi bir motivasvonla desteklenmeyen, sadece 'yapma', 'etme' şeklindeki yalın direktifler fazlaca etkili olmayacaktır. Bu noktada Budizm' in prensipleri uygulatmadaki en önemli şartı içtenlik/samimiyettir. (Kaya, 1999: 82, 83) Kant bunu 'iyi niyet' olarak belirlemiștir. Çünkü gerçekten herhangi bir somut yaptırıma dayanmadığı halde bir prensibin uygulanmasındaki temel koşul, zincirin son halkası, içtenlik veya başka bir adlandırmayla 'iyi niyettir'. Ancak Kant, 'iyi niyet'in, zincirin son halkası olmadığını, başka bir yaptırıma daha ihtiyaç olduğunu kabul etmiş ve oraya da Tanrı'yı koymuştur. (Barnes, 2002: 534) Diğer yandan Kant'tan farklı olarak, Tanrı inancını da benimsemeyen Budist öğretinin son halka olarak içselleştirme, benimsetme, samimiyeti güçlendirme ve bunları yaparken de eğitimi, benimsediğini söyleyebiliriz.

44 I P a g e 
Budizm'de ahlak öğretisi, herhangi bir otoritenin kötülükleri cezalandırması vb. bir argümana dayandırılmaksızın, doğrudan muhatabını öğreti doğrultusunda şekillendirmeyi esas almıştır. Yani Budist ahlak öğretisinde ahlaki yaptırım ne sosyal baskı ne de herhangi bir metafizik otoritedir. Müntesiplerine bir iç sorumluluk duygusu aşılamaya çalışan Budizm'e göre, doğramacıların ağaçlara şekil vermesi gibi iyi insan da kendini, sunulan prensipler doğrultusunda biçimlendirmelidir. (Kaya, 1999: 98)

Konfüçyanizm'de de aynı şekilde özgecilik, müntesiplere öğretilmeye çalışılan temel kavramdır. Yaşamın bütün safhalarında ölçülü olmak, fedakarlık, alçak gönüllülük ve doğallık sürekli taşınması gereken özelliklerdir. (Konfüçyüs, 1988: 50, 106, 107) Konfüçyüs'e (M.Ö. 551-479) göre, bir insan kendisine yapılmasını istemediği şeyi, başkasına yapmamalıdır. Çünkü ona göre erdem, bencil olmamak, kendisi için istediğini başkası için de istemek ve kişinin iç dünyasını temizlemesidir. (Konfüçyüs, 1988: $50,106,107)$ Konfüçyüs, insana yaşamı boyunca yol gösterecek bir prensip olup olmadığı şeklindeki bir soruya, 'doğru yanıt, cana yakınlık ve insanın kendisine yapılmasını istemediği bir şeyi başkasına yapmaması olmasın!' şeklinde karşılık vermiştir. (Konfüçyüs, 1988: 141) Konfüçyanizm'de de, Budizm'de olduğu gibi, bencillik (egoizm), yerilen bir olgudur. Öğretide sürekli bencillikten uzak olmanın üzerinde durulmuş, hoşgörü ve bağışlama öne çıkarılmıştır. Önyargıll, kesin ve katı hükümlü olmak kınanan bir durumdur. (Konfüçyüs, 1988: 81) Konfüçyanizm'de bu türden pek çok prensibin bulunması ve burada örneklendirilmesi mümkün olmakla birlikte, ele aldığımız problemin özüne uygun olarak bizim burada daha çok üzerinde durmak istediğimiz konu, bu prensipleri uygulatmak için ne tür bir eğitimin verildiği, prensipleri uygulaması için muhatabın ne şekilde yönlendirilmeye çalışıldığıdır.

Budizm'de olduğu gibi, Konfüçyanizm'de de prensiplerin hayata geçirilmesinde en önemli faktörlerden biri, onları içselleştirme ve içtenlik yani samimiyettir. (Konfüçyüs, 1988: 23; Konfüçyüs, 1997: 23, 24) Konfüçyüs'e göre prensipleri içselleştirmiş samimi insan, etik sorumluluk üstlenmiş insandır. Böyle bir sorumluluk üstlenmiş insan ise, önüne çıkan ne tür bir engel olursa olsun kararlı olmalı, taviz vermemelidir. (Konfüçyüs, 1988: 144) Öyle görülüyor ki, öğreti insana, yapıp ettiklerinin farkında olmayı şart koşarak, bir etik bilinç verme çabasındadır.

Anlaşıldığı kadarıyla Konfüçyanizm, öğreti içerisinde oranı çok önemli bir yer tutmasa da, Budizm'den farklı olarak bir sosyal baskı yaptırımı öngörmekte ve kötülük yapan insanın kınanmasını, ayıplanmasını da etik kuralların yerine getirilmesi, kötülüğün iyilikle yer değiştirmesi için bir çare görmektedir. Bütün çabalara rağmen, eğer birey, toplumda düzeni sağlayan kuralları ihlal etmeye, prensipleri benimseyip kendiliğinden uygulamaya yanaşmıyorsa, son çare olarak, sosyal baskının işletilmesini ileri sürmekle Konfüçyanizm Budizm'den ayrılmaktadır.

SONUÇ

Kohlberg, ahlaki yargı ile din arasında bir ilişki kurmaz ve ahlak gelişimini artırmada, bir dinin diğerine göre daha üstün olduğuna inanmaz.(Kohlberg, 1968:303) Bunun yanında, ahlaki ve dini gelişimin oldukça ayrı olduğu ve birbirine karıştırılmaması gerektiği konusunda çok net davranarak şu ifadelere yer verir:

Temel ahlaki prensiplerin belli bir dine ya da genel olarak dine dayandı $\breve{g}_{1}$ düşüncesi büyük bir yanılgıdır. Biz; Katolik, Protestan, Yahudi, Budist, Müslüman ve ateistlerin ahlaki düşünce gelişimleri arasında önemli bir fark tespit etmedik. Çocukların dini alandaki ahlaki değerleri, genel ahlaki sorgulamalarıyla aynı sırayı izler. Mesela, 2. basamaktaki bir çocuk, her halükarda 'Biz Tanrı'ya karşı iyi olursak, o da bize karşı iyi olur." diyecektir. Her ne kadar gerek kültürel değerler, gerekse din, ahlak yaşamındaki belli temaları seçici bir şekilde genişleten önemli faktörler olsalar da, temel ahlaki değerlerin gelişimindeki yegane kaynaklar değildirler. (Kohlberg 1974:13-14)

Kohlberg, tüm insan davranışlarının gelişimsel bir özellik arz etmesi nedeniyle, yaşanan dinin de gelişimsel olduğunu belirtir. $\mathrm{Bu}$ anlamda, bireylerin dini alandaki ahlaki değerlerinin, genel ahlaki değerlerinde olduğu gibi, aynı evreler doğrultusunda ilerlediğini söyler. Buna göre, birinci evrede Tanrı, ödül ve cezayı takdir eden bir otorite; ikinci evrede, kendisiyle pazarlık ilişkisinin kurulduğu bir varlık; üçüncü evrede, iyiliğin koruyucusu; dördüncü evrede, kanun koyucu ve düzenin nihai temeli ve beşinci evrede ise, ruhsal özgürlüğün, bireyselliğin ve sorumluluğun kaynağı olarak tasavvur edilir. Dolayısıyla Kohlberg, inanç gelişiminin, ahlaki yargı gelişimiyle paralel ilerlediğini fakat, ahlakın dinden bağımsız olduğunu savunur.(Kohlberg 1973:202)

Kohlberg, tüm insanların aynı inanca bağlı olmadığını, bu nedenle temel ahlak ilkelerinin de belirli bir dine bağlı olmaması gerektiğini belirtir. (Fowler, 1980:131-133, Scott 1992:467) Buna karş1lı, ahlaki prensiplerin yerine getirilmesi için inancın gerekli olduğunu şu ifadeleriyle belirtir: "Ahlaki prensiplerin oluşması ya da gerekçelendirilmesi için inanca gerek yoktur. Fakat yine de ahlaki prensiplere nihai olarak

45 I P a g e

www.iiste.org 
uymak için inanç bir bakıma gerekebilir.” (Kohlberg 1963:9-35) Bu bağlamda adalet prensibi uğruna ölen Sokrates ve Martin Luther King gibi ahlaki yargı gelişiminin 6. basamağında bulunan kişilerin, aynı zamanda derin bir şekilde dindar insanlar olduklarını da belirtmektedir. (Kohlberg 1984:151)

Tarihte olduğu gibi, çağdaş dünyada da ahlaken neyin doğru, neyin yanlış olduğu hakkındaki tartışmalar halen devam etmektedir. Geçmişte bir taraftan Sokrat, Aristo, Platon, Martin Luther King gibi toplum öncüleri, toplumun tümü tarafından benimsenecek davranış biçimlerini ararken, bir taraftan da başta peygamberler olmak üzere din adamları, dini kuralların benimsenmesi ile konuya çözüm getirmeye çalışmışlardır. Ancak toplumsal gelişmelerle birlikte, otoriter toplum yapıları güç kaybetmeye başlamış ve insan merkezli çalışmalara paralel olarak, statik değer yargılarının nesilden nesile aktarılmasının ahlak eğitimi için artık yeterli olmadığı görüşü benimsenmiştir. Öte yandan bilim ve teknolojinin hızlı gelişimiyle, dini değerlere karşı ilgi azalırken, bunun yerine seküler değerler ve seküler bir ahlak anlayışı ortaya çıkmaya başlamıştır. İşte Kohlberg, bu süreçte ahlaken neyin iyi neyin kötü olduğu konusunda mutlak otoriteyi insan aklına vermiştir. Ahlaki yargı hususunda, bilişe büyük bir öncelik vererek, herkesin kendi ahlaki tercihlerini kendisinin oluşturabileceğini ileri sürmüştür. Ne var ki, hak ve çıkarların çatışması halinde herkesin kendi çıkarlarını önceleyeceği böyle bir toplumda, ne bireysel ne de toplumsal düzeyde bir ahlaktan söz edilebilir. Bunun için, bireyi her halükarda ahlaki davranmaya sevk edecek üst bir otorite olmalıdır. İşte bu otorite de ancak "ilahi otorite" olabilir. Bu nedenle de tamamen dinden bağımsız bir ahlak düşünülemez.

Kohlberg'in ahlak eğitim uygulamaları, eksikleri olmakla birlikte, demokrasi eğitimi için de önemli bir modeldir. Ülkemizdeki ahlak gelişimi ve eğitimi konusundaki araştırmaların, yaşadığımız sorunlar göz önünde bulundurulduğunda yeterli olmadığı açıktır. Kohlberg'in teorisinde adalete, bireyin onuruna, biricikliğine, eşitliğine, özgürlüğüne, haklarını göz önünde bulundurmaya yönelik önemli imalar vardır. İşte Kohlberg'in ahlak eğitim modeli örnek alınıp, eksiklikleri giderilmeye ve bizim kültürümüze uyarlanmaya çalışılırsa, bireysel ve toplumsal ahlaki sorunlarımıza çözüm sunacak yeni yaklaşımlar geliştirmek mümkün olabilir.

\section{KAYNAKÇA}

ADAMS, J. F. “Ergenliği Anlamak.” Ankara, İmge Kitapevi 1995.

AKTAŞ, Yasin -KÖKTAŞ, Mehmet Emin, Din Sosyolojisi, Vadi Yay., Ankara 1998.

AKBOY, R, Eğitim Psikolojisi., Bornova Can Ofset, İzmir 1997.

ATICI, M., Bilgin, M., İnanç, B, Gelisim Psikolojisi; Çocuk ve Ergen Gelisimi, Nobel Yayınevi, Adana 2004.

AYDIN, A, Gelişim ve Öğrenme Psikolojisi., Anı Yayıncılık, 40-45; 187-203, Ankara 1999.

AYDIN, Fuat, Genel Hatlarıyla Yahudilik, İstanbul, 2004.

AYDIN Hayati, Kur'an’da İnsan Psikolojisi, Timaş Yay., İstanbul 1999.

AYDIN M., Eğitim Yönetimi., Hatipoğlu Yayınevi Ankara 1993.

AYDIN Mehmet, Hıristiyan Kaynaklarına Göre Hıristiyanlık, TDV Yay., Ankara, 2007.

AYDIN, Mehmet Zeki, Ahlak Öğretiminde Örnek Olay İncelemesi Yöntemi, Ankara: Nobel Yayinları, 2003.

AYDIN, Yusuf, Sinan Paşa’da Ahlak Anlayışı, İstanbul 2007.

BARNES, L. Philip, "Forgiveness, the Moral Law and Education: A Reply to Particia White", Journal of Philosophy of Education, 2002 Vol. 36 Issue 4, s. 529-544.

BOYES, M. C.; Walker, L. C. J, Implications of Cultural Diversity for the Universality Claims of Kohlberg's Theory of Moral Reasoning. Human Development, Vol, 1988, 31, 44-59. 
CARPENDALE, J.I.M., Kohlberg and Piaget on Stages and Moral Reasoning,Developmental Review, 2000.

ÇETİN, Hülya, İsa ve Ahlak öğretisi, Kriter yayıncılık İstanbul 2015.

ÇİFTÇİ, Neriman, Kohlberg'in Bilişsel Ahlak Gelişimi Teorisi: Ahlak ve Demokrasi Eğitimi, Değerler Eğitimi Dergisi 2000,1 (1); 43-77.

ÇİFTÇİ, Nermin, “Almanya ve Türkiye’deki Türk Lise Öğrencilerinin Ahlaki Yargı Yeteneklerinin Karşılaştırılması”, (Yayınlanmamış Doktora Tezi, MÜSBE, 2001).

ÇİLELİ, Meral, "14-18 Yaşları Arasındaki Öğrencilerde Ahlaki Yargının Zihinsel Gelişim Psikolojisi Yaklaşımı İle Değerlendirilmesi”, (Yayınlanmamış Doktora Tezi, AÜEBE, 1981).

ÇİLELİ, Meral, Ahlak Psikolojisi ve Eğitimi, Ankara: V Yayınları, 1986.

DEMIRİZ, S., Öğretir, A.D., Alt ve Üst Sosyo-Ekonomik Düzeydeki 10 Yaş Çocuklarının Anne Tutumlarının İncelenmesi, Kastamonu Eğitim Dergisi 2007.

DÖNMEZER, İ.,Gelişim ve Öğrenme Psikolojisi., Ege Üniversitesi Basımevi, İzmir 2004.

ERDEM, Hüsameddin, Ahlak Felsefesi, Hü-Er Yayınları, 2. Baskı, Konya, 2003.

ERDEM, M., Akman Y, Eğitim Psikolojisi, Gelişim-Öğrenme-Öğretme., Arkadaş Yayınları, Ankara 1995.

ERDEN. M.; AKMAN, Y., Gelişim ve Öğrenme-Öğretme. 8. Baskı, Ankara: Arkadaş Yayınevi 2000 .

ERSOY, N. M, “Adalet Alanında Çalısan ve Bu Konuda Eğitim Görenlerin Ahlaki Gelişim Evrelerinin İncelenmesi” Yayınlanmamıs yüksek lisans tezi, A.Ü. Sosyal Bilimler Enstitüsü, Ankara 1997.

FARABİ, Ebu Nasr, Fusûlü'l-Medenî (Siyaset Felsefesine Dair Görüşler), Çev. Hanifi Özcan, Dokuz Eylül Üniv. Yay., İzmir 1987.

FARUKİ İsmail Raci, Hıristiyan Ahlakı, Mahya Yay., 2011.

FOWLER, James, "Moral Stages and the Development of Faith", Moral Development, Moral Education, and Kohlberg, Brenda Munsey (Ed.), Birmingham, Alabama: Religious Education Press, 1980, ss. 130-160.

GLOCK, Charles Y., "Dindarlığın Boyutları Üzerine” (Aktay, Yasin - Köktaş, Mehmet Emin, Din Sosyolojisi içinde), Vadi Yay., Ankara 1998, s. 253.

GİBBS, John C, "Moral and Development\&Reality" Beyond the theories of Kohlberg, Hoffman, and Haidt,Oxford University Press, New York, 2014, s.81-93.

GÜÇ ,Ahmet, Çeşitli Dinlerde ve İslam’da Kurban, Düşünce Yay. İstanbul 2003.

GÜNGÖR, A., Gelişim ve Öğrenme, 2. Baskı, Anı Yayıncılık, Ankara 2003.

GÜNGÖR, Erol, Ahlak Psikolojisi ve Sosyal Ahlak., Ötüken Neşriyat A.Ş.,İstanbul 2010. Yayınlar1, 1993.

Değerler Psikolojsi, Amsterdam: Hollanda Türk Akademisyenler Birliği Vakfı

GÜNDÜZ, Şinasi Hıristiyanlık, İsam Yay., İstanbul, 2013. 
GÖZÜTOK, Ş., Erol Güngör'de Din ve Ahlak Eğitimi, Yüzüncü Yıl Üniversitesi, Sosyal Bilimler Enstitüsü, Yüksek Lisans Tezi, Van 2004.

HAYNES, Felicity., Eğitimde Etik., Çev. Akbaş SK., Ayrıntı Yayınları, Birinci Basım, İstanbul 2002.

HEINZ, Harbach, “Altruismus und Moral”Opladen: Westdt. Verl.,1992, s.48-49.

HÖKELEKLİ, Hayati, Din Psikolojisi, T.D.V.Yay., Ankara 1998.

LINN, Ruth "Conscience at War: On the Relationship Between Moral Psychology and Moral Resistance, Peace and Conflict", Journal of Peace Psychology, 7/4, 2001, s. 339.

KAĞITÇIBAŞI, Çiğdem, Benlik, Aile ve İnsan Gelişimi: Kültürel Psikoloji, İstanbul: Koç Üniversitesi Yayınları, 2010.

KREBS, D.L., DENTON, K., WARK, G., The Forms and Functions of Real-life Moral Decisionmaking, Journal of Moral Education, 26(2); 1997, s.131-145.

KÂTiP ÇELEBİ, Keşfu'z-Zunûn, İstanbul 1947, c.I, s.35.

KAYA, M., Kişilik Özelliklerinin Ahlaki Yargı Üzerine Etkisi, Din Eğitimi Araştırmaları Dergisi, 4; 1997.

KOHLBERG, Lawrence, “Beds for Bananas” Menorah Journal, 36, 1948, ss. 385-399.

, The Development of Modes of Thinking and Choices in Years 10 to 16, (Unpublished Doctoral Dissertation, University of Chicago, 1958).

, "Moral Development and Identification", Child Psychology: The Sixty-second Yearbook of National Society for Studies in Education, Herold W. Stevenson vd. (Ed.), Chicago: University of Chicago Press, 1963, ss. 277-332.

, "Moral Education in the Schools: A Developmental View", The School Review, 74/1, Spring 1966, ss. 1-30.

, "Early Education: A Cognitive-Developmental View", Child Development, 39/4, December 1968, ss. 1013-1062.

"The Claim to Moral Adequacy of a Highest Stage of Moral Judgment", The Journal of Philosophy, 70/18, (Seventieth Annual Meeting of the American Philosophical Association Eastern Division), October 1973, ss. 630-646.

1974, ss. 5-16

"Education, Moral Development and Faith", Journal of Moral Education, 4,

, "Moral Education for A Society in Moral Transition", Educational Leadership, 33, October 1975, ss. 46-54.

"Moral Stages and Moralization: The Cognitive Developmental Approach", Moral Development and Behavior: Theory, Research, and Social Issues, T. Lickona (Ed.), New York: Holt, Rinehart and Winston, 1976, ss. 31-53.

"Indoctrination versus Relativity", The Philosophy of Moral Development, New York: Harper \& Row, 1981, ss. 6-28.

, "A Reply to Owen Flanagan and Some Comments on the Puka-Goodpaster Exchange”, Ethics, 92/3, (Special Issue: Symposium on Moral Development), April 1982, ss. 513528. 
2), San Francisco: Harper \& Row, 1984.

KAYA, Korhan, Budistlerin Kutsal Kitapları, İmge Kitabevi, Ankara 1999.

KING, Robert H, Tanrı'nın Anlamı, çev. Temel Yeşilyurt, İnsan Yayınları, İstanbul 2001.

KONFÜÇYÜS, Söyleşimler, çev. İsmail Akyıldız, Gün Yayıncılık, İstanbul 1988.

1997.

Seçme Konuşmalar, çev. Hakan Arslanbenzer, 2. Baskı, Şule Yayınları, İstanbul

KULAKSIZOĞLU, A, Ergenlik Psikolojisi. 4. Basım, Remzi Kitapevi, İstanbu 2004.

KURTINES, William M. and J.L. Gewirtz (Eds.), Morality, Moral Behavior, and Moral Development, New York: John Wiley \& Sons. 1984.

KUTSAL KİTAP( Tevrat, Zebur, İncil), Yeni Yaşam Yay., İstanbul 2003.

MAVERDİ, Edebüd-Din ve Dünya, (Çev: Selahattin Kip, A. Sönmez), Bahar Yay., İstanbul 1978.

MORGAN, C. T. „Psikolojiye Giriş (Çev: Hüsnü Aracı ve Diğ. ) 8. Baskı,: Hacettepe Üniversitesi Psikoloji Bölümü Yayınları Yayın No:1., Ankara 1991.

OKUMUŞ, E., "Bir Din İstismarı Olarak Gösterişçi Dindarlık” İslâmiyât, c.5, sayı:4, Ankara 2002.

ONUR, B, Gelişim Psikolojisi., V Yayınları, Birinci Baskı, Ankara 1986.

ÖZLEM, Doğan, Etik Ahlak Felsefesi, 2. baskı, İstanbul 2010.

ÖZTÜRK, Recep Kur’an Penceresinden İnsan ve Mutluluk Yolları, Bayrak Matb., İstanbul 2004.

ÖZSÖZ, C., 14-18 Yaşları Arasındaki Suçlu ve Suçsuz Ergenlerde “Adaletsizlik" Yargısının Değerlendirilmesi, Ankara Üniversitesi Sosyal Bilimler Enstitüsü, Yüksek Lisans Tezi, Ankara 1990, s.80-82.

PAUL Tillich, Ahlak ve Ötesi, Elis Yay., Ankara, 2014.

PLATON, Devlet, çev. S. Eyüboğlu ve M. A. Cimcöz, İstanbul 1988, VI. Baskı, s.445

PIAGET, Jean, The M oral Judgment of the Child, (translated by Marjorie Gabain), New York: The Free Press, 1965.

PICKREN E Wade, Dewsbury Donald A., Wertheimer Michael, Portraits of Pioneers in Developmental Psychology, Psychology Press, London 1988, s.89-98.

RADEST, B. Howard, "From Clinic To Classroom" Medical Ethics and Moral Education, Printed in the United States of America 2000.

SARIKÇIOĞLU Ekrem, Din Fenomenolojisi, S.D.Ü.Yay., Isparta 2002.

SCOTT Richards, "Religious Bias in Moral Development Research: A Psychometric Investigation", Journal for the Scientific Study of Religion, 31/4, December 1992, s. 467.

SENEMOĞLU, N, Gelişim Öğrenme ve Öğretim, Kuramdan Uygulamaya., Gazi Kitabevi, 3. Baskı, Ankara 2001, s.148.

SERT H. Emin, Kuran'da İnsan Tipleri ve Davranışları, Bilge Yay., İstanbul 2004, s.31 
SPOHN, W.C., Conscience and Moral Development, Thelogical Studies, 1,2000.

TEMEL, F.Z., Aksoy, B.A., Ergen ve Gelişimi., Nobel Yayıncılık, Ankara 2001, s.67.

TURIEL, E.,"Developmental Processes In The Child's Moral Thinking, H. Mussen, J. M. Covington" (Eds). Trends and Issues in Developmental Psychology. Berkely: Universty of California 1969.

TOPÇU, Nurettin, Bergson, Dergah Yayınları, 2. Baskı, İstanbul 1998.

VERHOEF H., Michel, C., Studying Morality Within the African Context:A Model of Moral Analysis and Construction, Journal of Moral Education, 1997, Vol.26(4); 389- 408.

WALSH, Catherine, “The Life and Legacy of Lawrence Kohlberg”, Society, 37/2, January/February 2000, ss. 36-41.

WHITE, Richard D., Jr., “Are Women More Ethical? Recent Findings on the Effects of Gender Upon Moral Development”, Journal of Public Administration Research and Theory: J-PART, 9/3, Jun 1999, ss. 459-471.

YAPICI, Ş.; YapıcıI, M, Gelişim ve Öğrenme Psikolojisi, Anı Yayıncılık, Ankara 2005.

YILDIZ, Murat, "Dindarlığın Tanımı ve Boyutları Üzerine Psikolojik Bir Çalışma”, TabulaRasa, say1: I, Isparta 2001, 